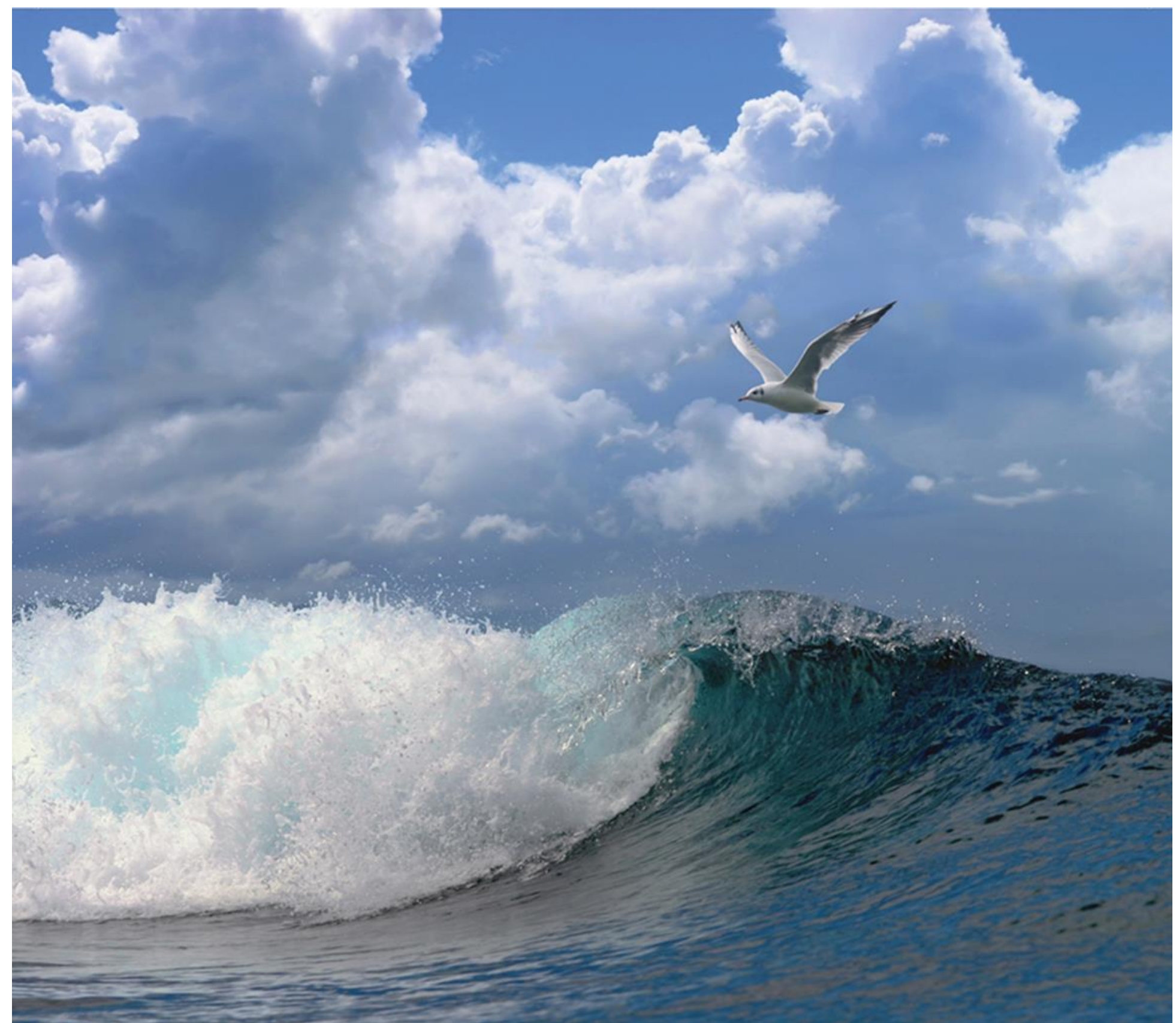

Monitoring bodemdieren in beoogde bestortingsgebieden bij de ontgrondingskuilen nabij de Oosterscheldekering 


\section{Monitoring bodemdieren in beoogde bestortingsgebieden bij de ontgrondingskuilen nabij de Oosterscheldekering}

Auteur(s): $\quad$ Vincent Escaravage, Lisanne van den Bogaart, Tom Ysebaert 
Keywords: ontgrondingskuilen, Oosterscheldekering, stormvloedkering, macrobenthos, Natura 2000

\author{
Opdrachtgever: T.a.v.: Gerry Schoonen, Adviseur Omgeving \\ Rijkswaterstaat Zee \& Delta \\ Poelendaelesingel 18 | 4335 JA Middelburg
}

Dit rapport is gratis te downloaden van https://doi.org/10.18174/514687

Wageningen Marine Research verstrekt geen gedrukte exemplaren van rapporten.

Wageningen Marine Research is ISO 9001:2015 gecertificeerd.

(C) Wageningen Marine Research

Wageningen Marine Research, instituut binnen de rechtspersoon Stichting

Wageningen Research, hierbij vertegenwoordigd door Dr. M.C.Th. Scholten, Algemeen directeur

KvK nr. 09098104,

WMR BTW nr. NL 8113.83.696.B16.

Code BIC/SWIFT address: RABONL2U

IBAN code: NL 73 RABO 0373599285
Wageningen Marine Research aanvaardt geen aansprakelijkheid voor gevolgschade, noch voor schade welke voortvloeit uit toepassingen van de resultaten van werkzaamheden of andere gegevens verkregen van Wageningen Marine Research. Opdrachtgever vrijwaart Wageningen Marine Research van aanspraken van derden in verband met deze toepassing.

Alle rechten voorbehouden. Niets uit deze uitgave mag weergegeven en/of gepubliceerd worden, gefotokopieerd of op enige andere manier gebruikt worden zonder schriftelijke toestemming van de uitgever of auteur. 


\section{Inhoud}

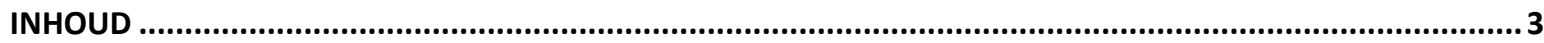

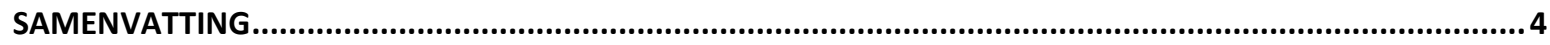

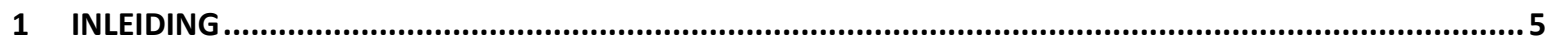

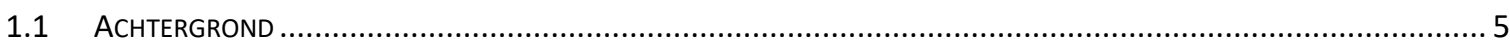

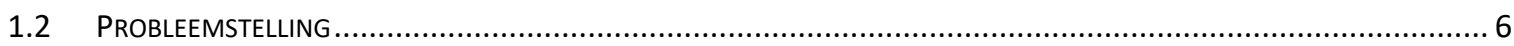

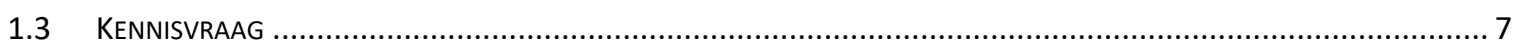

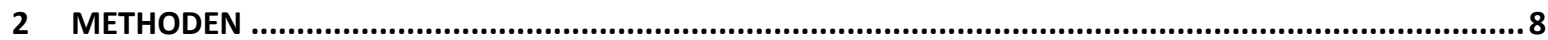

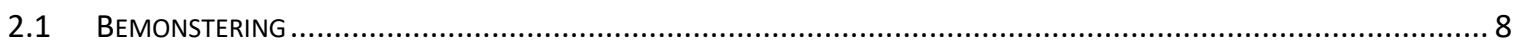

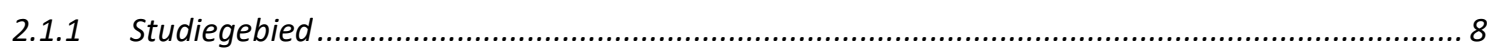

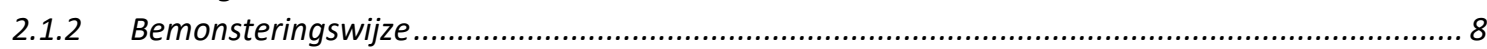

2.1.3 Aantal monsterlocaties zoals bepaald voor het monitoringsprogramma................................. 9

2.1.4 Uitvoering van de veldwerkzaamheden ........................................................................... 9

2.1.5 Veldwaarnemingen m.b.t. de inhoud van de monsters ........................................................... 10

2.1.6 Aantal uitgezochte monsters zoals bepaald o.b.v. uitvoerbaarheid......................................... 10

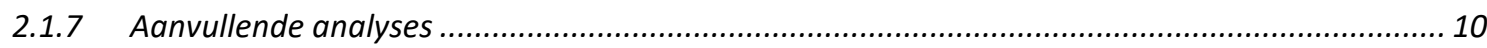

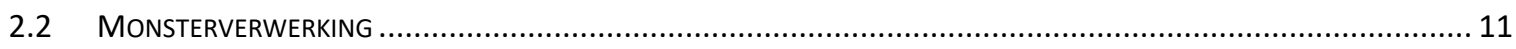

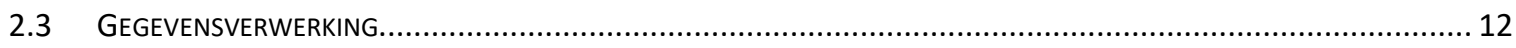

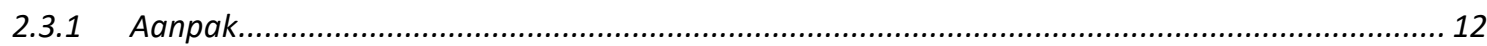

2.3.2 Naar een ecologische waardering van de studiegebieden ...................................................... 12

2.3.3 Statistische toetsing voor de ecologische waardering ......................................................... 12

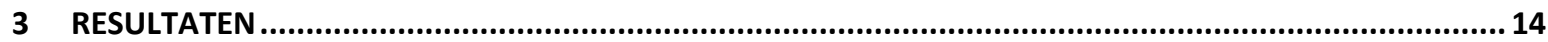

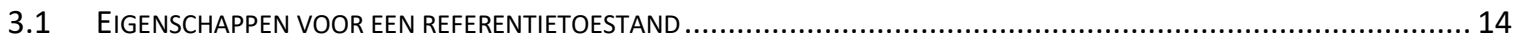

3.1.1 Typische soorten uit de LNV Natura 2000-habitattypen .................................................... 14

3.1.2 Statistische eigenschappen van gemeenschappen uit de grote monitoringprogramma's.......... 14

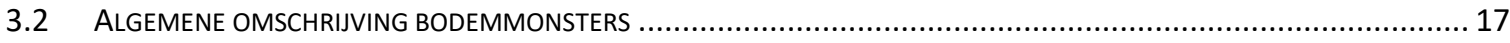

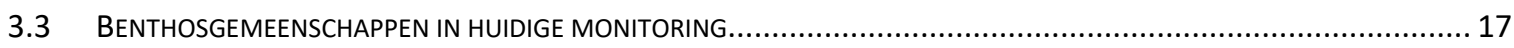

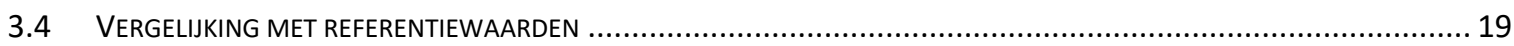

3.4.1 Mate van overeenkomst met Natura 2000-habitat soortenlijsten........................................... 19

3.4.2 Mate van overeenkomst met soortenrijkdom monitoringsprogramma's .................................. 19

3.4.3 Mate van overeenkomst met soortensamenstelling monitoringsprogramma's ....................... 20

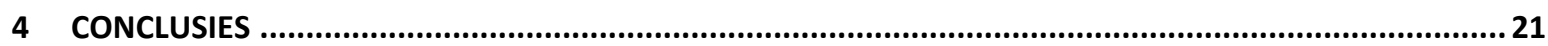

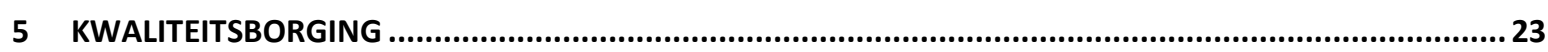

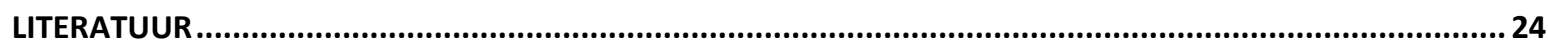




\section{Samenvatting}

Deze studie onderzoekt de ecologische kwaliteit van de ontgrondingskuilen ter hoogte van de Oosterscheldekering. Deze ontgrondingskuilen tasten de bodembescherming van de kering aan en dienen versterkt te worden d.m.v. bestortingen. Het bestorten van de ontgrondingskuilen zal effecten hebben op het bodemleven dat hier voorkomt. In hoeverre het hier om rijke bodemdiergemeenschappen gaat met tevens het voorkomen van typische Natura 2000-soorten is echter onvoldoende bekend. De verwachting is dat in de ontgrondingskuilen, door het extreme dynamische karakter (zeer hoge stroomsnelheden), een vrij homogene zandige bodem voorkomt met weinig bodemleven, en de bodemdiergemeenschappen als verarmde versies van de gemiddelde bodemdiergemeenschappen horende bij dit ecotoop (hoogdynamisch, diep gelegen) beschouwd kunnen worden. Deze studie heeft aan de hand van bodemdierenmonsters onderzocht of deze veronderstelling bevestigd kan worden.

De bodem van de ontgrondingskuilen bleek in de meeste gevallen grof van samenstelling te zijn, bestaande uit gruis, schelpen en stenen, met een grote variatie tussen de monsters. Dit bemoeilijkte de bemonstering, met tot gevolg een soms geringe hapdiepte (door de aanwezigheid van schelpen en stenen) en grote volumes monsters (door de grote hoeveelheid aan gruis en grind). Dit leidde tot aanpassingen in het aantal uitgewerkte monsters en het protocol voor de uitwerking van de monsters. Toch is het met de verzamelde informatie mogelijk gebleken de onderzoeksvraag te beantwoorden.

In totaal zijn er 132 taxa onderscheiden in de 20 onderzochte monsters; 95 taxa zijn waargenomen in de monsters aan de Oosterscheldezijde van de kering, en 98 taxa aan de Voordeltazijde. In vergelijking met de MWTL en PMR-NCV monitoringsprogramma's behoren de waargenomen waarden van soortenrijkdom tot representatieve niveaus voor respectievelijk de Oosterschelde en de Voordelta.

Verschillende typische soorten van het habitattype H1160 (OS, grote baaien) en H1110 (VD, permanent overstroomde zandbanken) worden in de ontgrondingskuilen waargenomen. Vergeleken met het habitattype $\mathrm{H} 1160$ ontbreken aan de Oosterscheldezijde van de kering een aantal soorten, maar dit zijn eerder soorten van intergetijdengebieden en ondiepe sublitorale gebieden zoals de kokkel, zeeduizendpoot en wadpier. Vergeleken met het habitattype H1110 ontbreken aan de Voordeltazijde van de kering de zeeklit en de, vaak met de zeeklit geassocieerde, ovale zeeklitschelp. Deze organismen leven ingegraven in zandige tot slibrijke bodems, terwijl de ontgrondingskuilen eerder bestaan uit grovere bodems met gruis, schelpen en stenen. De bodemdiergemeenschap in de ontgrondingskuilen is zeer gevarieerd: de monsters variëren sterk in zowel het aantal taxa, de densiteit en de biomassa, met een aantal zeer rijke monsters met hoge aantallen en biomassa. Opvallend is de dominantie van een aantal epibentische soorten zoals zeeanemonen (Actiniaria), brokkelsterren (Ophiura, Ophiothrix), en zeesterren (Asterias rubens) die op de grovere bodem een geschikt habitat aantreffen. Daarnaast valt de aanwezigheid van kokerwormen op, zoals de schelpkokerworm Lanice conchilega en de pauwenstaart-viltkokerworm Sabella pavonina. De witte boormossel werd op één locatie, ingeboord in verharde klei, in hoge dichtheden en biomassa aangetroffen. In deze grovere bodems komen ook heel wat kleinere soorten wormen voor, zoals Oligochaeta en Mediomastus sp. Heel wat soorten die frequent voorkomen in de monitoringsprogramma's in de Oosterschelde (MWTL) en de Voordelta (PMR-NCV) worden ook in de ontgrondingskuilen aangetroffen, maar verschillen vaak in frequentie van voorkomen; tezamen met de afwezigheid van sommige soorten wijst het op een typische bodemdiergemeenschap in de ontgrondingskuilen.

Er kan dus gesteld worden dat de huidige locaties van de ontgrondingskuilen uiteenlopende leefhabitats tonen met, lokaal, hoge soortenrijkdom, aantallen en biomassa's aan bodemdieren en met verschillende soorten die als typische soorten kwalificeren binnen de Natura 2000-habitats H1160 en H1110. Ook in de meest soortenarme stations komen kwalificerende soorten voor (zoals de zandzager Nephtys cirrosa). De ontgrondingskuilen herbergen een typische bodemdiergemeenschap, horende bij dit dynamische milieu. Ondanks de hoogdynamische omstandigheden, kunnen heel wat soorten zich vestigen in deze grovere bodems. Het gaat daarbij om zowel epibenthische soorten, als soorten die genieten van de bescherming van een eigen koker (kokerwormen). Kokerwormen vormen daarbij een leefgebied voor heel wat andere, kleinere soorten. De huidige bevindingen spreken dus de verwachting tegen dat de ontgrondingskuilen slechts verarmde bodemdiergemeenschappen zonder typische Natura 2000-soorten zouden herbergen. 


\section{$1 \quad$ Inleiding}

\section{$1.1 \quad$ Achtergrond}

Bij de aanleg van de Oosterscheldekering is aan weerszijden van de kering bodembescherming aangebracht over een breedte van 550 meter (Schaar) en 650 meter (Hammen en Roompot) (Figuur 1). Aan beide zijden van de Oosterscheldekering zijn langs de randen van de bestaande bodembescherming ontgrondingskuilen ontstaan. Deze tasten de bodembescherming aan. In 2012 werd geconstateerd dat op een aantal plaatsen de rand van de bodembescherming verzakt, beschadigd of zelfs verdwenen was. Deze constatering was de aanleiding voor noodbestortingen in 2012 en 2013 aan de Roompot Oostzijde (Stoutjesdijk et al., 2012).

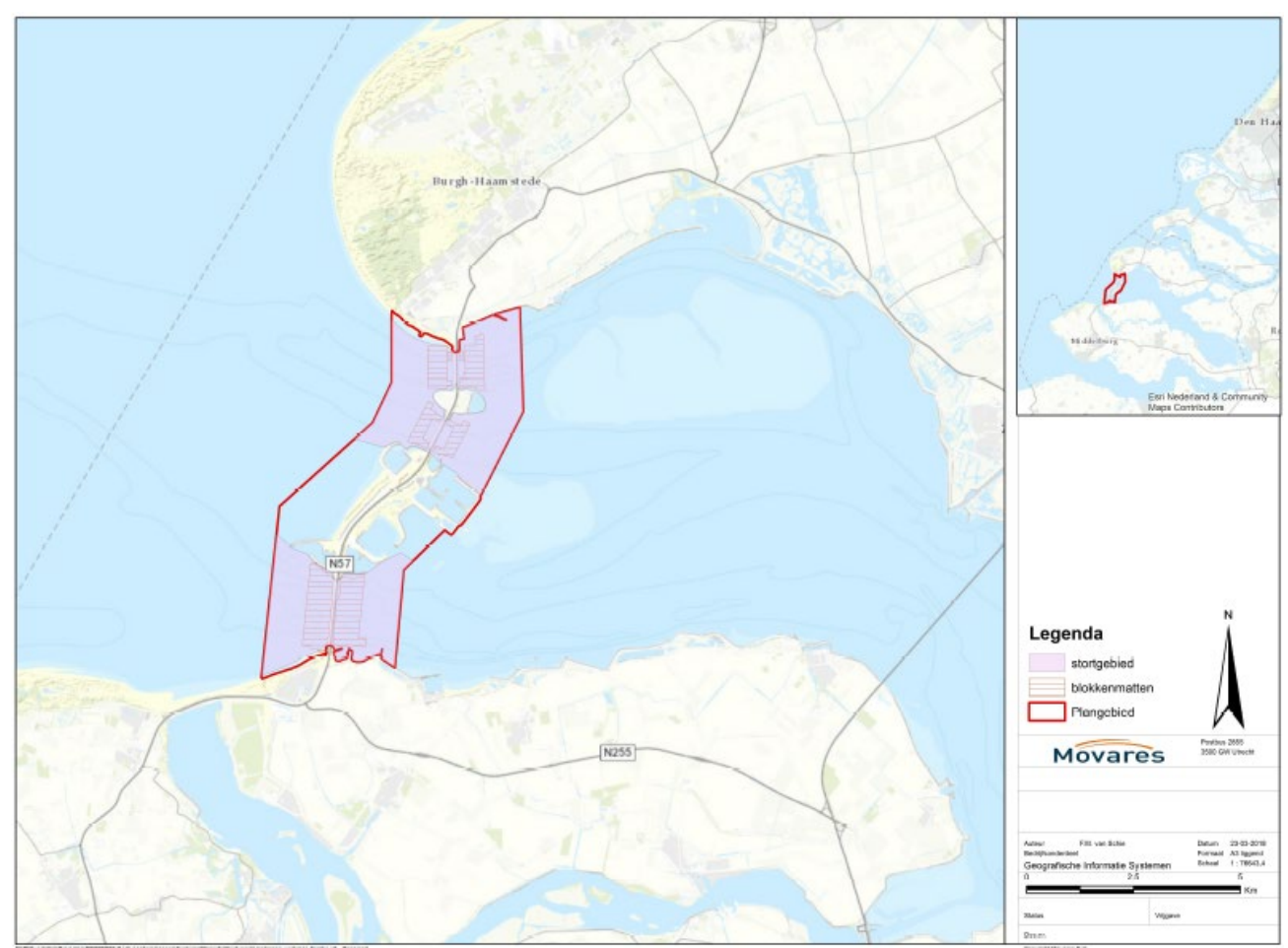

Figuur 1: Ligging plangebied gebaseerd op de shapefile 'contourOSK_plangebied'. Overgenomen uit Van der Woude \& van Schie (2019).

Derhalve is Rijkswaterstaat voornemens om in de komende jaren nieuwe bestortingen uit te voeren aan weerszijden van de Oosterscheldekering om de helling en/of bodem van de kuil te stabiliseren. Deze werkzaamheden zijn noodzakelijk om verdere erosie van de ontgrondingskuilen tegen te gaan en de integriteit van de bodembescherming van de Oosterscheldekering te waarborgen.

Het bestortingsmateriaal bestaat uit waterbouwkundig granulair materiaal. De werkzaamheden vinden in zijn geheel onder de laagwaterlijn plaats. De bestortingen worden op en tegen de bestaande bodembescherming rond de kering aangelegd. De totale oppervlakte van het projectgebied is 2.728 hectare (zie Figuur 1). Op basis van peilgegevens van de afgelopen jaren is het de verwachting dat er komende 5 jaar maximaal 27 hectare 'zacht' substraat bestort moet worden. Dit komt neer op net iets minder dan $1 \%$ van het projectgebied. Het ligt in de lijn der verwachting dat het merendeel van de bestortingen plaats vindt in de stroomgeulen Schaar, Hammen en Roompot. 


\section{$1.2 \quad$ Probleemstelling}

De ontgrondingskuilen liggen binnen de Natura 2000-gebieden Oosterschelde en Voordelta (Figuur 2). Daarnaast grenst het plangebied aan het Natura 2000-gebied Kop van Schouwen. Zowel de Oosterschelde als de Voordelta zijn aangewezen als Habitat- en Vogelrichtlijn gebied. Kop van schouwen is alleen aangewezen als Habitatrichtlijn gebied. In figuur 2 is de ligging van deze drie Natura 2000gebieden weergegeven. De geplande bestortingen vinden dus plaats binnen het Natura 2000-gebied Voordelta en het Natura 2000-gebied Oosterschelde.

Het gaat om de volgende geulen: Schaar, Hammen en Roompot. De geplande werkzaamheden zijn een voortzetting van werkzaamheden die afgelopen jaren zijn uitgevoerd. Hiervoor is op 11 februari 2014 een vergunning in het kader van de Natuurbeschermingswet 1998 afgegeven. De vergunning Natuurbeschermingswet verloopt op 31 december 2019. Een nieuwe vergunning is noodzakelijk en hiervoor is een de Passende Beoordeling uitgevoerd Van der Woude \& van Schie (2019).

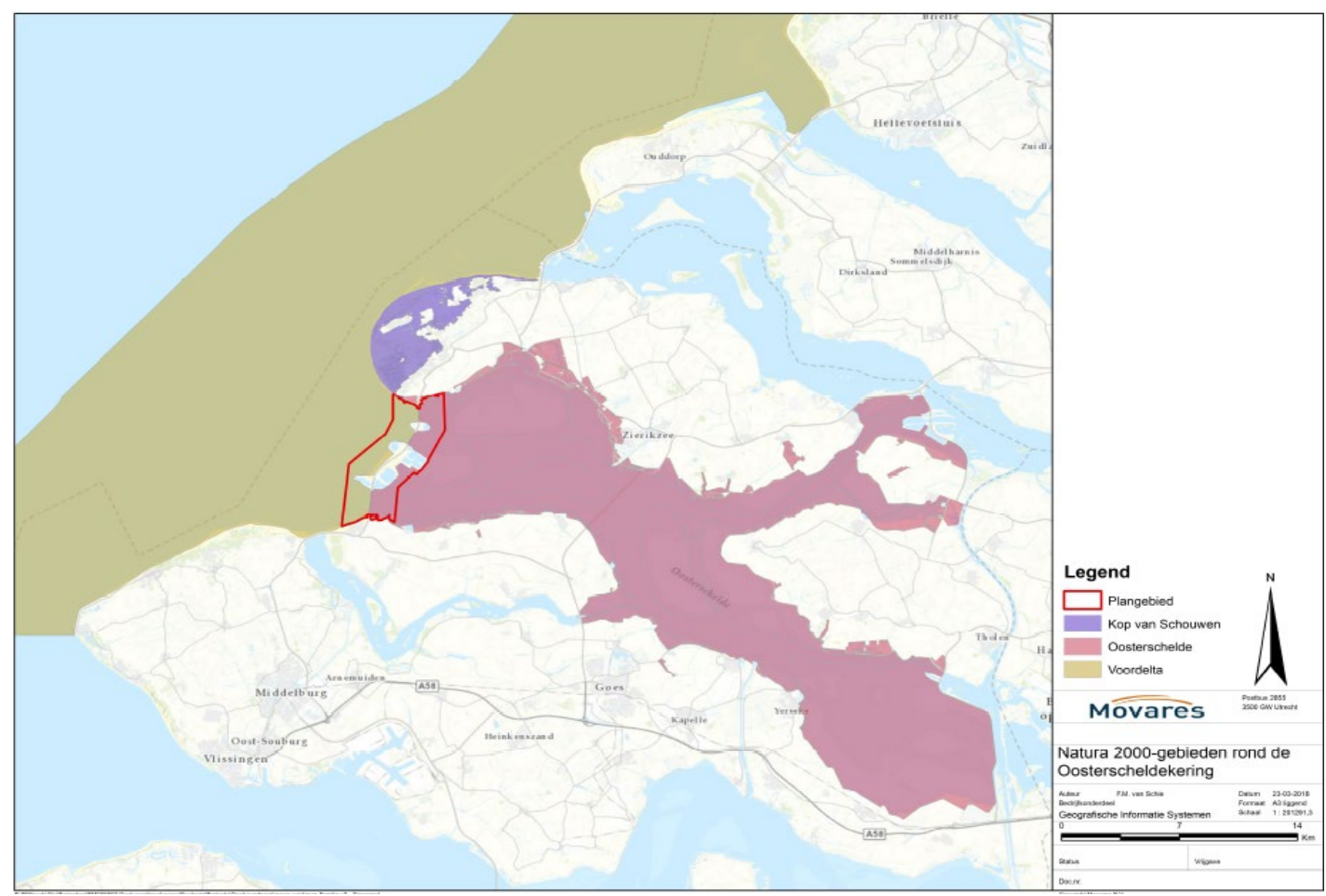

Figuur 2: Natura 2000-gebieden in (de omgeving van) het plangebied. Overgenomen uit Van der Woude \& van Schie (2019).

De passende beoordeling heeft in kaart gebracht wat de effecten zijn van de voorgenomen werkzaamheden op de instandhoudingsdoelstellingen van de omliggende Natura 2000-gebieden (Van der Woude \& van Schie, 2019). Het doel hierbij was om zo veel mogelijk informatie te verzamelen om te bepalen of de ingreep kan leiden tot overtredingen van de wetten en regels die toezien op bescherming van de natuur.

In de passende beoordeling wordt benadrukt dat de huidige ecologische kwaliteit van het te bestorten gebied niet bekend is maar dat de verwachting is dat het habitat ter plaatse weinig ecologische waarde heeft door het slecht vestigingsklimaat als gevolg van de hoge dynamiek rond de kering (Movares, 2019). Deze grote dynamiek uit zich in de hoge stroomsnelheden die hier voorkomen op grote diepte (tot 65 m - NAP), en de sterke erosie. Om dit vermoeden van lage ecologische kwaliteit te kunnen toetsen, wordt in de passende beoordeling voorgesteld om, voorafgaand aan de bestortingen, een viertal willekeurige $T_{0}$ metingen aan beide zijden van de Oosterscheldekering te doen. Zoals benadrukt wordt door Van der Woude \& van Schie (2019), dienen de gestelde aannames, zowel met betrekking tot de verwachte ecologische kwaliteit van het te bestorten gebied, als voor het voorgestelde aantal te nemen $\mathrm{T}_{0}$ bodemmonsters, degelijk gestaafd te worden met een passend onderzoek. 


\section{$1.3 \quad$ Kennisvraag}

De kennisvraag voor de huidige studie werd als volgt geformuleerd in de opdrachtomschrijving:

Kunnen diepe ontgrondingskuilen met hoge stroomsnelheden in de Oosterschelde en de Voordelta aangemerkt worden als kwalitatief goed habitattype, zoals wettelijk zijn aangewezen in deze Natura 2000-gebieden? Het antwoord dient gebaseerd te worden op 1) een inventarisatie van de bodemfauna op hoog-dynamische plaatsen in de Oosterschelde en de Voordelta op plaatsen die bestort moeten worden en 2) een vergelijking van de resultaten hiervan met referentiewaarnemingen.

Gelet op het geringe oppervlak aan habitat dat verloren gaat door de bestorting (0,04\% van de 35.100 ha in de Oosterschelde en $0,017 \%$ van de 81.225 ha in de Voordelta (Van der Woude \& van Schie, 2019)), spitst de eerste kennisvraag zich vooral toe op soorten die specifiek in die gebieden gehuisvest zouden kunnen zijn vergeleken met de Natura 2000-habitats die getypeerd zijn voor die gebieden.

Bij de keuze van de referentiewaarden in het kader van de tweede kennisvraag wordt, voor de vergelijking met de gegevens uit deze studie, rekening gehouden met het ecotoop waartoe de ontgrondingskuilen behoren (d.i. hoogdynamisch sublitoraal). 


\section{Methoden}

\section{$2.1 \quad$ Bemonstering}

\subsubsection{Studiegebied}

De contouren van de zes studiegebieden werden aangeleverd door de opdrachtgever in de vorm van GIS shapefiles (Figuur 3).

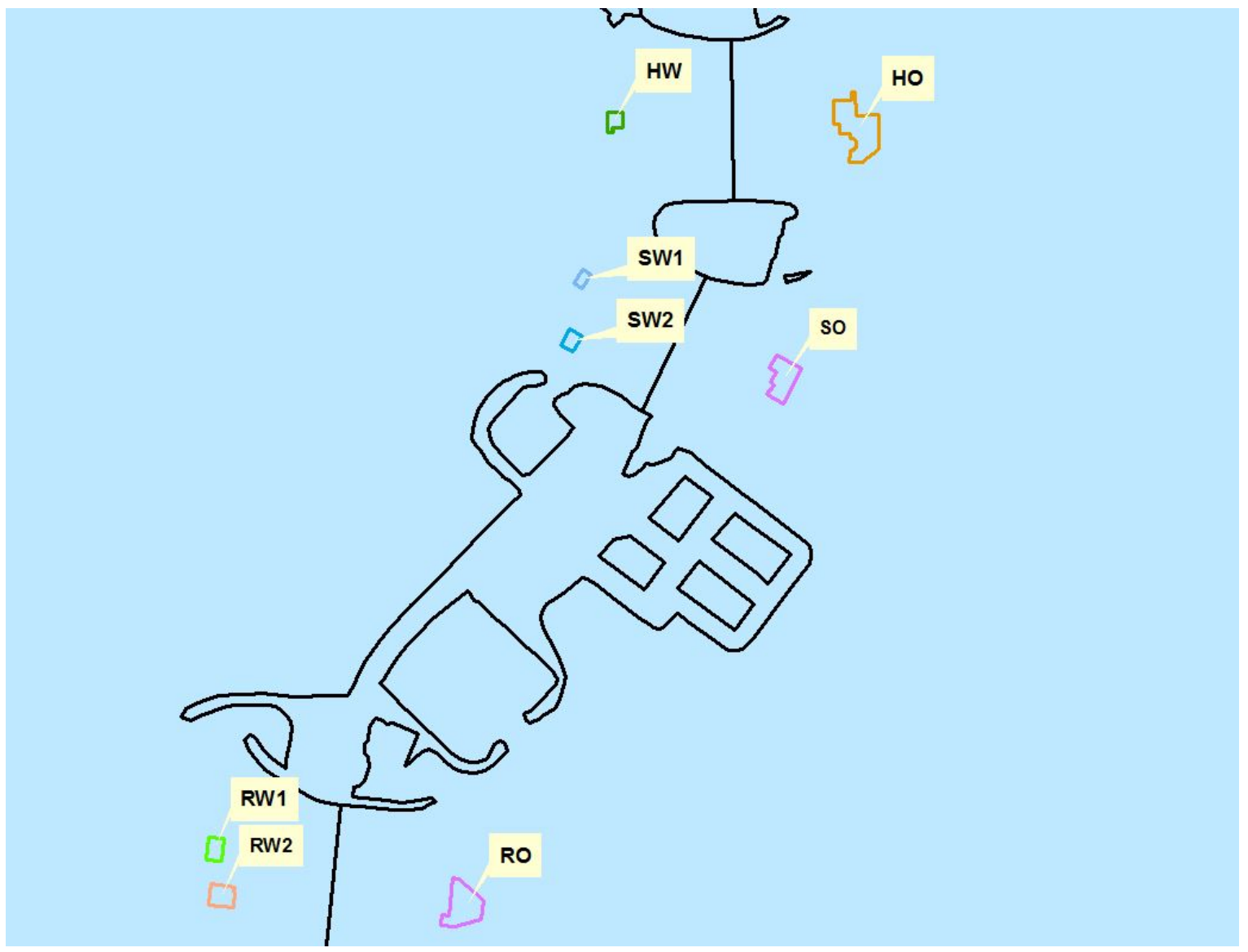

Figuur 3: Overzicht van de studiegebieden aan beide zijden van de Oosterscheldekering HO (Hammen Oost), HW (Hammen West), SO (Schaar Oost), SW1 en SW2 (Schaar West 1 en 2), RO (Roompot Oost), RW1 en RW2 (Roompot West 1 en 2).

De gebieden Schaar West en Roompot West werden verdeeld in twee deelgebieden (SW1/SW2, RW1/RW2). Vanwege de aanwezigheid van bestortingsmateriaal in deze gebieden was het namelijk niet mogelijk om de bemonstering uit te voeren zoals gepland en derhalve is aan weerszijden van het bestortingsmateriaal bemonsterd.

\subsubsection{Bemonsteringswijze}

Door de sterke stroming, grote helling en mogelijke aanwezigheid van stenen, leent het studiegebied zich niet goed voor bemonsteringen met gesleepte tuigen zoals kor of schaaf waardoor gekozen is voor een bemonstering met een boxcorer (type Reineck, 0,078 $\mathrm{m}^{2}$ ). De monsters worden gezeefd op een zeef met maaswijdte van $1 \mathrm{~mm}$ (RWS voorschrift 913.00.B200, v7). Doordat de Reineck boxcorer ook gebruikt wordt in het kader van andere monitoringprojecten in de Oosterschelde (MWTL: Monitoring Waterstaatkundige Toestand des Lands) en de Voordelta (PMR-NCV: Project Mainport Rotterdam Natuurcompensatie Voordelta), maakt die keuze het tevens mogelijk om onderlinge vergelijkingen te maken met die projecten. 
Het betonningschip "Frans Naerebout" werd ingezet door de opdrachtgever voor de huidige monitoring. Dankzij de DPS (Dynamic Positioning System) kan het schip zich nauwkeurig positioneren op de locatie gepland voor de bemonstering. Per locatie werd naast het bodemdierenmonster ook een sedimentmonster genomen ter typering van de bodemsamenstelling van de monsterlocatie (RWS voorschrift 913.00.B200, v7).

\subsubsection{Aantal monsterlocaties zoals bepaald voor het monitoringsprogramma.}

Het aantal monsters per gebied is geoptimaliseerd op basis van de ratio tussen de toename in de trefkans van soorten en de verhoging in het aantal monsters per locatie. Voor deze bepaling is gebruik gemaakt van een simulatie voor de berekening van de trefkans van individuen uit een denkbeeldige populatie met een random verdeling op de bodem als functie van hun dichtheid en voor toenemend monsteroppervlak (Figuur 4). Deze bepaling kan beschouwd worden als een kosten-baten met de verhoging in de soortentrefkans als baten en het aantal monsters per locatie als kosten (bemonstering en analyse kosten).
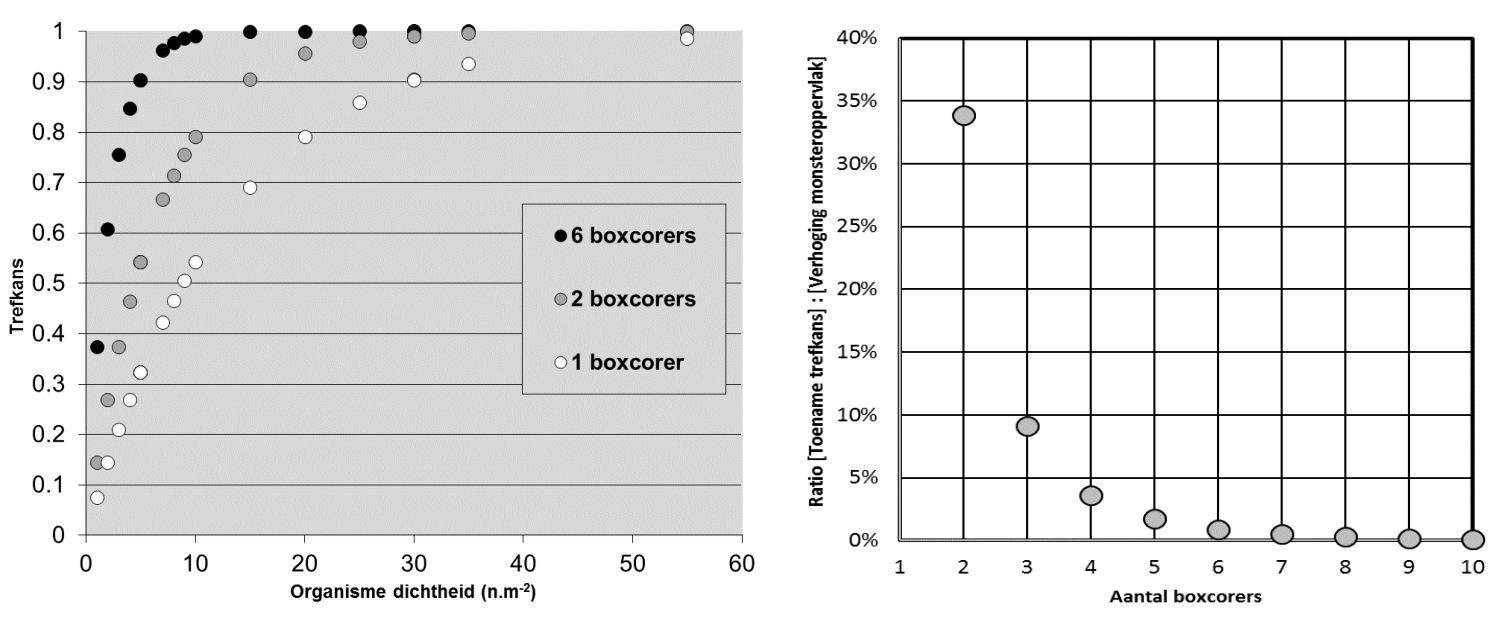

Figuur 4: Links: Trefkans voor soorten (met een random verdeling op de bodem) in 1, 2 en 6 boxcorers als functie van hun dichtheid. Rechts: Relatieve winst (verhoging in trefkans) gewogen met de toename in monsteroppervlak als functie van het aantal (2 tot 10) boxcorers.

De berekening voor een dichtheid van 5 individuen per $\mathrm{m}^{2}$ laat zien dat de relatieve winst geboekt met het verhogen van het aantal monsters verwaarloosbaar wordt voor meer dan 6 boxcorers per locatie (Figuur 4). Op basis van dit resultaat is besloten om, ruimtedekkend, zes monsters per gebied (drie per deelgebied bij Roompot West en Schaar West) te verzamelen en dus in totaal 36 monsters voor de huidige To monitoring (Bijlage 1 tot Bijlage 3).

\subsubsection{Uitvoering van de veldwerkzaamheden}

Een overzicht van de locaties bemonsterd voor de analyse van de benthos gemeenschap is weergegeven in Bijlage $1 \mathrm{t} / \mathrm{m}$ Bijlage 3. Door de aanwezigheid van stenen en schelpen konden in totaal vier van de 36 monsters (HW_06, HO_01, RW1_02, RO_04) niet op de geplande locaties genomen worden. Daarnaast dienden op één locatie twee keer onderdelen van de boxcorer (ketels en scheppen) vervangen te worden doordat deze beschadigd waren geraakt vanwege de aanwezigheid van hard substraat (HW_06 verplaatst naar HW_07). Voor de overige drie locaties die niet bemonsterd konden worden, is gezocht naar alternatieve locaties (HO_07, RW1_04, RO_07). Alle alternatieve locaties konden binnen de beoogde studiegebieden geplaatst worden, m.u.v. HW_07. Hier was de toegang tot het gebied verhinderd door verschuiving van de veiligheidslijn onder invloed van het uitgaande water (zie Bijlage 1).

Door de moeilijke omstandigheden (o.a. sterke stroming, grote diepte) en de aanwezigheid van stenen, schelpen en gruis kon vaak de voorgeschreven hapdiepte van $15 \mathrm{~cm}$ niet gehaald worden. Hierdoor kan het zijn dat soorten die dieper in het sediment leven in deze monsters gemist worden. Toch werd de informatieve waarde van deze monsters als afdoende beschouwd voor het krijgen van inzicht in de 
bodemdiergemeenschappen die in de ontgrondingskuilen voorkomen. Derhalve is besloten om deze monsters te behouden.

\subsubsection{Veldwaarnemingen m.b.t. de inhoud van de monsters}

Onderliggend aan de benadering gebruikt bij het configureren van het monitoringsprogramma (§ 2.1.3) gold de aanname m.b.t. de monstergebieden van "homogene zandige, hoogdynamische bodems met relatief weinig leven". Deze aanname was gebaseerd op de rapportage van Van der Woude \& van Schie (2019) waar verondersteld werd dat het habitat ter plaatse een lage ecologische waarde zou hebben door het slechte vestigingsklimaat als gevolg van de hoge dynamiek rond de kering. Tijdens de bemonstering bleek snel dat de studiegebieden echt anders waren dan "homogene zandige, hoogdynamiche bodems met relatief weinig leven".

Bijlage 4 geeft een overzicht van de verscheidenheid in de monsters m.b.t. samenstelling, van mosselpeulen en gruis tot stenen, met daartussen de opmerkelijke aanwezigheid in sommige monsters van vele slang-/brokkelsteren, zeeanemonen en kokerwormen. Tijdens de bemonster blijkt dat de hoeveelheid materiaal dat op de zeef achterblijft enorm varieert tussen de monsters $(0,5$ tot 8 liter voor de monsters getoond in Bijlage 4). De monsters zijn omvangrijker (gemiddeld 91 op basis van alle monsters en maximaal 201 per monster) en rijker aan fauna dan werd verwacht op basis van de passende beoordeling (Van der Woude \& van Schie, 2019). Dit kwam onder andere door de aanwezigheid van grote hoeveelheden schelpenresten en grind en/of stenen.

\subsubsection{Aantal uitgezochte monsters zoals bepaald o.b.v. uitvoerbaarheid}

De bodemsamenstelling en soortenrijkdom (op basis van voorlopige beschouwingen in 2.1.5 en Bijlage 4) van de monsters komen duidelijk niet overeen met de aanname die centraal stond bij de configuratie van het huidige monitoringsprogramma (zes monsters per gebied, uitgaande van een homogeen zandig gebied).

In heterogene omgevingen dient een groot aantal monsters genomen te worden langs de aanwezige gradiënten (bijv. door middel van een gestratificeerde monitoring) om zo goed mogelijk rekening te kunnen houden met de natuurlijke variatie. In afwezigheid van een dergelijke stratificatie in het monitoringsprogramma verzwakt de relatie tussen de toename in het aantal monsters en de nauwkeurigheid van de waarnemingen. Daardoor is het niet gegarandeerd dat de nauwkeurigheid die bereikt is met zes monsters groter is dan op basis van bijv. vier monsters.

Een meer triviaal maar niet minder doorslaggevend aspect i.v.m. de omvang en rijkdom van de monsters is dat de volledige afwerking van 36 monsters zou zorgen voor een overschrijding (ca. verdubbeling) van het projectbudget en tijdsbestek met een oplevering in april 2020. Naar aanleiding van deze observaties is, in overleg met de opdrachtgever, besloten om de uitzoekwerkzaamheden te beperken tot 20 (i.p.v. 36) monsterlocaties. Deze locaties zijn ruimtelijk verdeeld over de studiegebieden (zie Bijlage 5). Deze vermindering van het aantal monsters maakt het mogelijk om de resultaten tijdig af te leveren. Daarbij is tevens rekening gehouden met het evenwicht tussen de ingezette capaciteit t.o.v. de bereikbare nauwkeurigheid van de waarnemingen.

\subsubsection{Aanvullende analyses}

Als aanvulling op de analyse van de 20 geanalyseerde monsters werden de bodemdierengemeenschappen in de overige 16 monsters gescreend (quickscan) na het zeven van de monsters op een zeef met maaswijdte van $1 \mathrm{~mm}$ (zie Bijlage 6).

De sedimentanalyse van de sedimentmonsters, verzameld in combinatie met de bodemdiermonsters, staan weergegeven in Bijlage 11. De korrelgrootteverdeling van de zandfractie is bepaald met een Malvern (Laser Diffraction Particle Size Analyser) volgens standaard protocol door het NIOZ. 


\subsection{Monsterverwerking}

De verwerking van de monsters vond plaats volgens het RWS-analysevoorschrift A2-107 v7. Volgens dit protocol is het toegestaan om het monster te decanteren over een $500 \mu \mathrm{m}$ zeef, waardoor de fauna grotendeels gescheiden kan worden van de sedimentmatrix (Figuur 5).

De twee fracties verkregen bij deze procedure (i.e. een fijne fractie die door de zeef gaat en het decantaat dat in de spoelbak overblijft) worden beiden apart uitgezocht op bodemdieren. Na het volledig uitzoeken, wordt het decantaat tarra genoemd. De tarra kan gebruikt worden om te controleren hoe nauwkeurig de werkzaamheden zijn uitgevoerd door te zoeken naar overgebleven organismen.

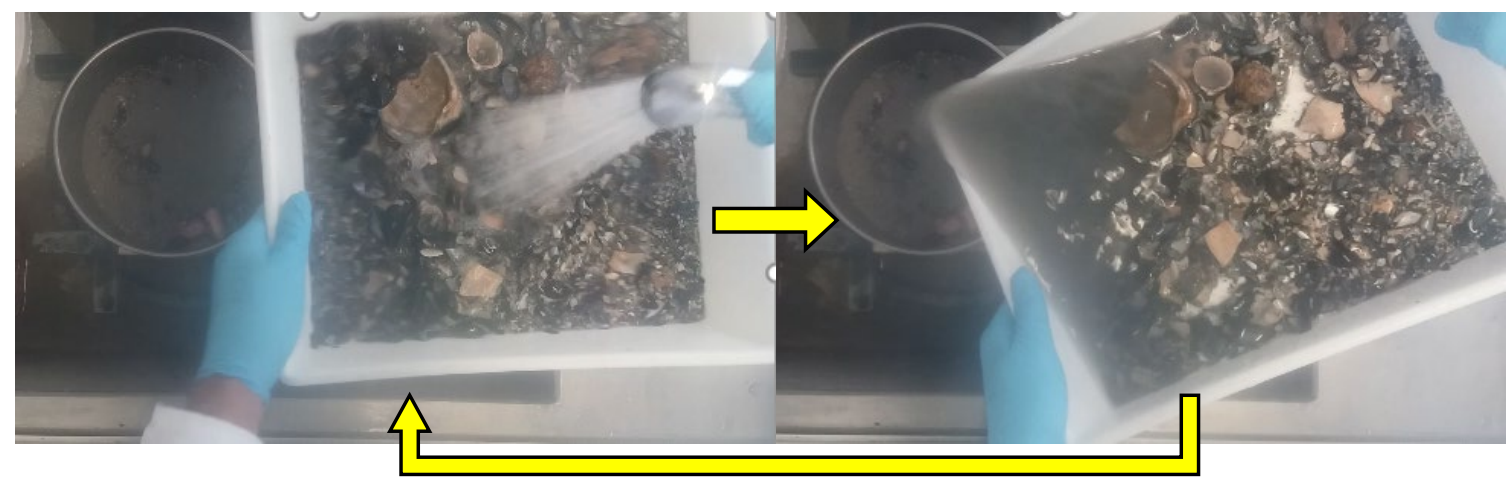

Figuur 5: Decanteren van een monster waar een fractie (een laag sediment in een fotobak) minimaal tien keer gespoeld wordt over een $500 \mu \mathrm{m}$ zeef totdat geen zichtbaar organisme meer overgegoten wordt.

Door de grote volumes van de monsters, was het niet realistisch om de monsters integraal uit te zoeken zoals voorgeschreven in het analysevoorschrift van Rijkswaterstaat (A2-107 v7). Volgens het protocol dient het gebruik van deelmonsters beperkt te blijven tot de soorten waar meer dan 100 individuen van in de monsters voorkomen.

In overleg met Joël Cuperus van RWS-CIV is afgesproken om, voor omvangrijke monsters ( $>4 \mathrm{~L})$, slechts 4 liters uit het decantaat volledig uit te zoeken op bodemdieren en vervolgens op te slaan als "doorgezochte tarra". De resterende fractie van het decantaat is grof doorzocht op grotere organismen die moeilijk in suspensie raken tijdens het decanteren en vervolgens opgeslagen als "gescreende tarra".

De organismen zijn daarna geconserveerd in 4\% formaldehyde en bewaard tot determinatie. Het uitgezochte restmateriaal is daarna weer opgeslagen in de betreffende monsterpot (eveneens in $4 \%$ formaldehyde) en opgeslagen. Alle organismen werden vervolgens, indien mogelijk, gedetermineerd tot op soortniveau. Als dit niet mogelijk was, werden de organismen gedetermineerd tot het eerstvolgende hogere niveau. Na determinatie is de biomassa, in de vorm van het asvrij drooggewicht (Ash-Free Dry Weight, AFDW) bepaald. Waar mogelijk is het AFDW van individuele taxa per monster bepaald. Van abundante schelpdiersoorten zijn in een aantal gevallen lengte-AFDW regressies gemaakt per gebied. Voor een aantal kleinere taxa is de biomassa geschat. Van ieder taxon is minimaal één exemplaar achtergehouden voor controle door RWS en de referentiecollectie van Rijkswaterstaat.

Sommige monsters bleken zeer bewerkelijk, met name de monsters met veel schelpkokerwormen (Lanice conchilega) en Hydrozoa. Tussen de kokers en de tentakels van schelpkokerwormen kunnen zich zeer kleine wormen, vlokreeftjes, slangsterren of schelpdieren bevinden. Het gaat daarbij vaak om individuen die kleiner zijn dan $1 \mathrm{~mm}$ en normaal gesproken niet op de zeef zouden achterblijven. Door hun minimale lengte kunnen deze echter wel gemist worden bij het uitzoeken.

Wageningen Marine Research heeft de doorgezochte tarra van drie monsters ter controle naar RWS gestuurd. Hiervan is één monster in detail uitgezocht, namelijk het monster SW1-02 (Schaar West1 02). Dit controlemonsters werd ook door RWS als erg bewerkelijk omschreven. Dit monster is door RWS met een binoculair uitgezocht, wat niet het protocol is dat WMR volgt (uitzoeken zonder binoculair). In totaal bleek $13 \%$ van het totaal aantal organismen nog aanwezig te zijn in het tarra monster. Het gaat daarbij vooral om Oligochaeta, kleine Amphipoda, kleine schelpdieren (Abra, Bivalvia, Kurtiella en Mytilus), juveniele Ophiuridae en kleine polychaeta (vooral Terebellida). Er zijn geen voorschriften over hoeveel individuen aanvaardbaar gemist kunnen worden in een monster, maar 13\% werd door RWS en 
WMR als een relatief hoog percentage beoordeeld. WMR heeft daarom besloten een aantal doorgezochte tarra opnieuw uit te zoeken om na te gaan in hoeverre dit door RWS uitgezochte monster representatief is voor alle monsters of uitzonderlijk door de aanwezigheid van grote hoeveelheden schelpkokerwormen en Hydrozoa. In de vier opnieuw uitgezochte monsters (HW-02, HW-03, RW2-03, SO-04) varieerde het aantal gemiste individuen van $0,9 \%$ tot $9,2 \%$. Vooral kleine schelpdieren en kleine slang-/brokkelsterren werden gemist in deze grote bewerkelijke monsters. Deze zijn achtergebleven in het gruis en schelpen na het decanteren. Om het percentage gemiste individuen in de toekomst te verlagen, gaat WMR de tarra van zulke monsters voortaan met een binoculair uitzoeken.

Benadrukt dient te worden dat deze gemiste individuen voor de vraagstelling ("Kan de bodemdiergemeenschap in de ontgrondingskuilen als kwalificerend voor de Natura 2000-habitattypes beschouwd worden?") volgens ons geen gevolgen heeft.

\subsection{Gegevensverwerking}

\subsubsection{Aanpak}

Beide deelgebieden, Oosterschelde (OS, Oost van de Oosterscheldekering) en Voordelta (VD, West van de Oosterscheldekering), worden getypeerd op basis van drie eigenschapen. Hiertoe worden de bodemdiergegevens van de ontgrondingskuilen vergeleken met de soortenlijsten uit de LNV Natura 2000-habitattypen en referentiewaarden verkregen uit de bodemdiergegevens van de MWTL en PMRNCV monitoringsprogramma's:

- Soortenlijsten op basis van alle monsters in elk gebied (OS en VD) vergelijken met de soortenlijsten uit de Natura 2000-Habitattypen (H1160 en H1110B).

- Aantal soorten op basis van alle monsters in elke gebied (Oost en West) vergelijken met het aantal soorten gevonden voor hetzelfde monsteroppervlak op hoogte van het vijfde percentiel van de monsters uit de referentiedatasets (MWTL/Oosterschelde, PMR-NCV/Voordelta).

- Voorkomingsfrequentie van soorten in $>90 \%,>50 \%-<90 \%,<50 \%$ van de monsters in elke gebied (Oost en West) vergelijken met de voorkomingsfrequentie voor hetzelfde monsteroppervlak in de referentiedatasets (MWTL, Oosterschelde; PMR-NCV, Voordelta).

\subsubsection{Naar een ecologische waardering van de studiegebieden}

De eerste onderzoeksvraag betreft de ecologische kwaliteit van de ontgrondingskuilen in vergelijking met de Natura 2000-habitats waar de kuilen zich bevinden: H1160 (Grote baaien) in de Oosterschelde en H1110 (Permanent overstroomde zandbanken) in de Voordelta. Gelet op het geringe oppervlak aan habitat dat verloren gaat door de bestorting $(0,04 \%$ van de 35.100 ha in de Oosterschelde en 0,017 \% van de 81.225 ha in de Voordelta (Van der Woude \& van Schie, 2019)), richt de eerste onderzoeksvraag zich vooral op soorten die specifiek in die gebieden gehuisvest zouden kunnen zijn.

Op basis van de monsters verzameld in elk deelgebied (OS en VD) zijn soortenlijsten opgesteld en vergeleken met de lijsten van typische soorten zoals aangereikt in de Profielhabitattype documenten (LNV Natura 2000, Profielen habitattypen en soorten). Op basis van deze vergelijking wordt vastgesteld hoe de studiegebieden zich verhouden ten opzichte van de Natura 2000-habitattypen. Er wordt onderzocht of de typische soorten voor de genoemde Natura2000-habitats zich ook in het studiegebied bevinden.

\subsubsection{Statistische toetsing voor de ecologische wardering}

De vergelijking met de Natura 2000 soortenlijsten (zie 2.3.2) laat niet toe om de macrobenthosgemeenschap uit de studiegebieden op statistische wijze te vergelijken met referentiewaarden. Om daaraan te voldoen wordt gebruik gemaakt van benthosgegevens verzameld in vergelijkbare ecotopen (hoogdynamisch sublitoraal) uit bestaande monitoringprogramma's (PMR-NCV in Voordelta, MWTL in de Oosterschelde) verkregen van Informatiehuis Marien. De vergelijking is uitgevoerd op basis van het aantal soorten en van de lijst van soorten gevonden in de huidige monitoring en in de referentiedatasets. Beide indicatoren (aantal soorten en soortenlijst) zijn sterk afhankelijk van het aantal monsters volgens de "soort-oppervlakte kromme" die de relatie beschrijft tussen het aantal soorten en het bemonsterde oppervlak. Ten behoeve van de huidige vergelijking moet dus de 
statistische verdeling van het aantal soorten en van de soortenlijst berekend worden over het aantal monsters in de referentiedataset (zie 2.3.2.1 en 2.3.2.2). De vergelijking vindt vervolgens plaats tussen deze statistische waarden en de huidige resultaten.

\subsubsection{Aantal soorten}

Het aantal waar te nemen soorten in een selectie van monsters is rechtstreeks afhankelijk van het bemonsteringsoppervlak. Daardoor is het niet mogelijk om het aantal soorten gevonden in de tiental monsters in de huidige dataset rechtstreeks te vergelijken met het aantal soorten gevonden in de honderden monsters uit de referentiedataset. Om een dergelijke vergelijking te kunnen maken is gebruik gemaakt van permutatie technieken (Fortran routine geprogrammeerd door dr. Peter Herman (Deltares), pers. com.). Daarin is het aantal soorten, gevonden in alle mogelijke combinaties van het aantal monsters uit de referentiedataset, berekend en weergegeven als functie van het bemonsteringsoppervlak. Deze exercitie levert, voor elk gerealiseerd bemonsteringsoppervlak, de frequentieverdeling (percentielen) van het aantal soorten en dus ook voor het totale oppervlak bemonsterd voor de huidige dataset. Bij soortenrijkdom kleiner dan het $5^{\text {de }}$ percentiel, dan wel groter dan de $95^{\text {de }}$ percentiel, worden de studiegebieden beschreven als respectievelijk arm en rijk.

\subsubsection{Soortenlijsten}

Op basis van de twee referentiedatasets (OS en VD) is de frequentie van voorkomen bepaald van iedere soort/taxon. Deze frequentie van voorkomen wordt vergeleken met de frequentie van voorkomen in de huidige monitoring. Daarnaast zijn drie soortenlijsten opgesteld: (1) soorten aanwezig in meer dan $90 \%$, (2) tussen $50 \%$ en $90 \%$ en (3) in minder dan $50 \%$ van alle waarnemingen in de referentiedatasets. Voor elke soortenlijst wordt een minimaal aantal soorten verwacht in de huidige monitoring. Hierbij is rekening gehouden met het feit dat waarnemingen van soorten bepaald worden door hun trefkans (i.e. functie van de verwachte voorkomensfrequentie en van het monsteroppervlak, berekend op basis van een Poisson verdeling). Deze trefkansfunctie staat weergegeven in Figuur 6 met, voor elke soortenlijst (>90\%, 50\%-90\%, <50\%), het minimale aantal soorten te verwachten in de huidige monitoring als functie van het aantal soorten waargenomen in de referentiedataset.

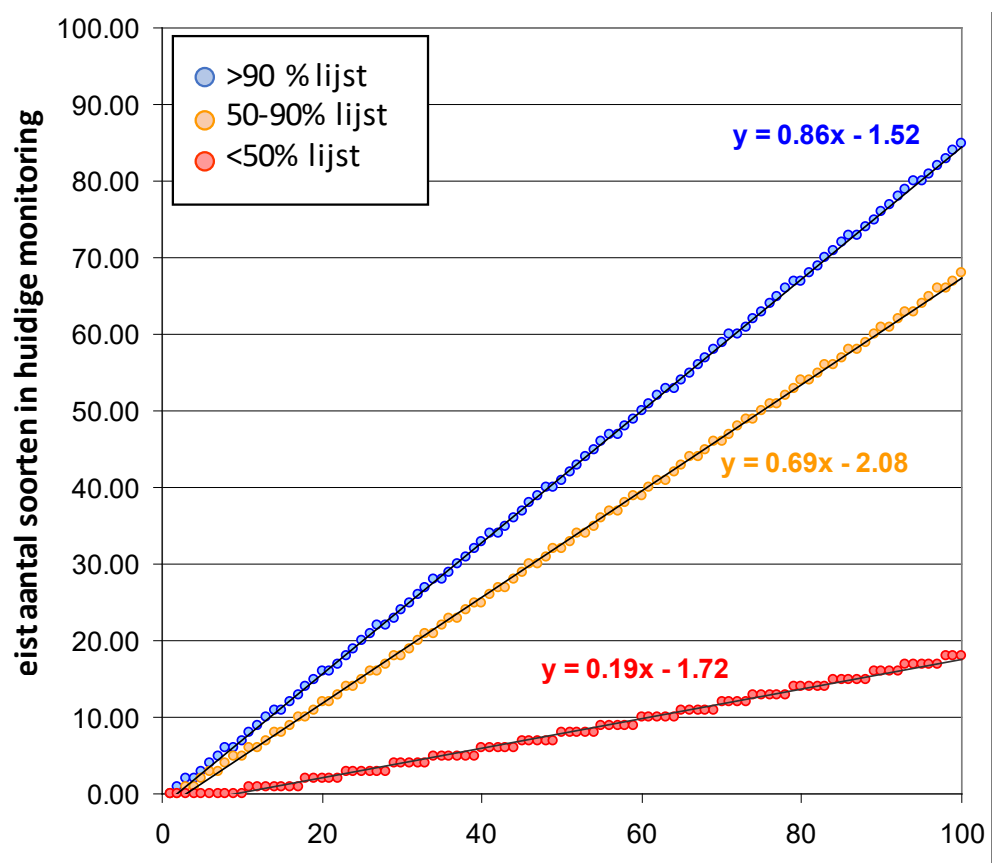

Figuur 6: Minimaal aantal soorten te verwachten in de huidige monitoring als functie van het aantal soorten in de $<90 \%, 50-90 \%$ en $<50 \%$ lijsten uit de referentiedatasets. 


\subsection{Eigenschappen voor een referentietoestand}

\subsubsection{Typische soorten uit de LNV Natura 2000-habitattypen}

Bij de karakterisering van de gemeenschappen waargenomen in de huidige monitoring aan beide zijden van de kering (Oost, Oosterschelde en West, Voordelta) is als referentie gebruik gemaakt van de Natura 2000-habitattypen soortenlijst zoals hieronder beschreven.

\subsubsection{Oosterschelde}

Habitattype H1160 'Grote baaien' telt 10 typische bodemdierensoorten (Bijlage 7) waarvan twee grote soorten (Metridium senile en Carcinus maenas) gerekend als indicatie voor een goede abiotische toestand en goede biotische structuur. De overige acht soorten (eveneens van relatief grote omvang), waaronder kokkel, mossel, hartegel, zeeduizendpoot, schelpkokerworm en wadpier zijn gerekend als indicatie voor een goede abiotische toestand.

\subsubsection{Voordelta}

Habitattype H1110B (permanent overstroomde dynamische zandbanken, Noordzee-kustzone tot $20 \mathrm{~m}$ ) telt 12 typische bodemdierensoorten (Bijlage 8) waarvan de schelpkokerworm (Lanice conchilega) en de zandkokerworm (Spiophanes bombyx) zijn gerekend als indicatie voor een goede abiotische toestand en goede biotische structuur. De overige tien soorten, waaronder kleine wormen, kreeftachtigen en de gewone slangster, zijn gerekend als indicatie voor een goede abiotische toestand.

\subsubsection{Statistische eigenschappen van gemeenschappen uit de grote monitoringprogramma's}

Voorafgaand aan de statistische berekeningen m.b.t. de bodemdiergemeenschappen is er een selectie gemaakt van monsters van de beschikbare monitoringgegevens (MWTL en PMR-NCV) op basis van omgevingskarakteristieken vergelijkbaar met de huidige monitoring.

Voor de Oosterschelde monsters (MWTL 2009-2017) is een selectie gemaakt van de monsters behorende tot het hoogdynamisch diep ecotoop (OSZHDDP) dieper van 5 meters t.o.v. NAP. Die laatste inperking is bedoeld om monsters onder invloed van golfwerking uit te sluiten en dit leidt tot een selectie van 144 monsters. Een nadere selectie van monsters uit dieper gelegen locaties, meer in de buurt van de huidige survey, leidt tot een drastisch afname van het aantal locaties. Om een goede vergelijking te maken tussen de Oosterschelde monsters en de Voordelta monsters, is het wenselijk aan beide zijden een gelijkaardig aantal monsters te hebben. Met betrekking tot de Voordelta monsters (PMR-NCV 20042017) is er een selectie gemaakt van de monsters dieper dan 20 m, allen gerekend tot hoog dynamische locaties, wat leidt tot een selectie van 224 locaties.

De volgende statistieken zijn gebruikt in de vergelijking tussen de huidige bemonstering en de monitoring gegevens (MWTL, Oosterschelde en PMR-NCV, Voordelta):

- Aantal soorten bij het $5^{\text {de }}$ percentiel van de verdeling van alle combinaties van monsters voor een monsteroppervlak van $0,78 \mathrm{~m}^{2}$ (alle tien monsters Oost of West uit het huidige onderzoek) (zie tabel 1 en tabel 2). Bij soortenrijkdom kleiner dan de $5^{\text {de }}$ percentiel dan wel groter dan de $95^{\text {de }}$ percentiel worden de studiegebieden beschreven als respectievelijk arm en rijk.

- Voorkomingsfrequentie van soorten in meer dan $90 \%, 50 \%$ tot $90 \%$ en in minder dan $50 \%$ van de monsters met een oppervlak van $0,078 \mathrm{~m}^{2}$ (één monster uit het huidige onderzoek) (zie tabel en tabel 2). 
Tabel 1: Statistische waarden voor het aantal taxa en de voorkomingsfrequentie van taxa berekend op basis van de Oosterschelde gegevens (MWTL 2009-2017) op hoog dynamische sublitoral locaties dieper dan $5 \mathrm{~m}$ ( $n=144$ locaties).

\section{Oosterschelde}

\section{\begin{tabular}{|l|l}
\hline Aantal taxa & Voorkomingsfrequentie taxa
\end{tabular} \\ 73 taxa in $5 \%$ van de monsters samengevoegd tot 1 taxa in meer dan $90 \%$ van de monsters} een monsteroppervlak van $0,78 \mathrm{~m}^{2}$

2 tot 3 taxa in 50 tot $90 \%$ van de monsters

69 taxa in 10 tot $50 \%$ van de monsters

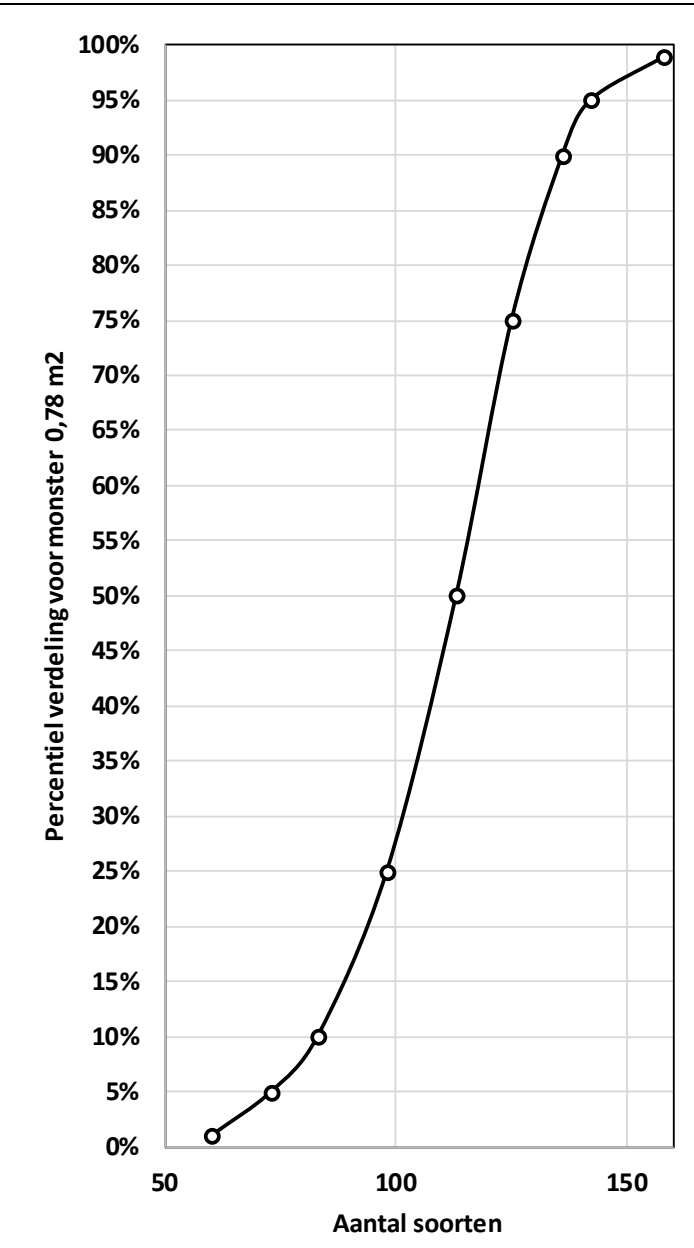

\begin{tabular}{|l|l|}
\hline Soort & Frequentie
\end{tabular}

\begin{tabular}{|l|l|}
\hline Scoloplos armiger & $96 \%$ \\
\hline Spiophan & $83 \%$ \\
\hline
\end{tabular}

Spiophanes bombvx $\quad 83 \%$

\begin{tabular}{l|l} 
Nephtys & $67 \%$ \\
\hline
\end{tabular}

\begin{tabular}{l|l} 
Nephtys cirrosa & $66 \%$ \\
\hline
\end{tabular}

\begin{tabular}{l|l} 
Abra alba & $44 \%$ \\
\hline
\end{tabular}

Lanice conchileqa $42 \%$

\begin{tabular}{l|l} 
Magelona iohnstoni & $41 \%$
\end{tabular}

\begin{tabular}{l|l}
\hline Oliaochaeta & $40 \%$ \\
\hline
\end{tabular}

\begin{tabular}{l|l} 
Nephtys homberaii & $37 \%$
\end{tabular}

$\begin{array}{ll}\text { Urothoe poseidonis } & 35 \%\end{array}$

\begin{tabular}{l|l} 
Cirratulidae & $35 \%$ \\
\hline
\end{tabular}

\begin{tabular}{l|l} 
Nemertea & $35 \%$
\end{tabular}

Notomastus latericeus $\quad 32 \%$

\begin{tabular}{l|l} 
Capitella & $30 \%$ \\
\hline Poecilochaetus serpens & $30 \%$
\end{tabular}

Actiniaria $\quad 30 \%$

Aricidea (Aricidea) minuta $\quad 29 \%$

\begin{tabular}{l|l} 
Kurtiella bidentata & $28 \%$
\end{tabular}

Urothoe brevicornis $\quad 28 \%$

\begin{tabular}{l|l} 
Mvtilidae & $26 \%$ \\
\hline
\end{tabular}

\begin{tabular}{l|l} 
Glvcera tridactvla & $26 \%$ \\
\hline
\end{tabular}

Pseudopolvdora pulchra $\quad 26 \%$

Fabulina fabula $\quad 24 \%$

\begin{tabular}{ll} 
Abludomelita obtusata & $24 \%$ \\
\hline
\end{tabular}

Pholoe inornata $24 \%$

Eunereis lonaissima $\quad 23 \%$

\begin{tabular}{ll} 
Echinocardium cordatum & $22 \%$ \\
\hline
\end{tabular}

\begin{tabular}{l|l} 
Glycera & $22 \%$ \\
\hline
\end{tabular}

Spio martinensis $20 \%$

\begin{tabular}{l|l}
\hline Aoridae & $20 \%$ \\
\hline Tellimva ferruainosa & $20 \%$ \\
\hline
\end{tabular}

\begin{tabular}{l|l} 
Polynoidae & $20 \%$
\end{tabular}

\begin{tabular}{l|l}
\hline Tellinoidea & $19 \%$
\end{tabular}

\begin{tabular}{l|l} 
Phyllodoce mucosa & $19 \%$ \\
\hline
\end{tabular}

Ensis $18 \%$

\begin{tabular}{ll}
\hline Ampelisca brevicornis & $17 \%$ \\
\hline Anodlodactvlus petiolatus & $17 \%$ \\
\hline
\end{tabular}

Pariambus tvpicus $17 \%$

Ophiuroidea $16 \%$

$\begin{array}{ll}\text { Bathvooreia eleaans } & 16 \%\end{array}$

Phvllodoce $16 \%$

Sthenelais boa $15 \%$

\begin{tabular}{l|l} 
Ophiura ophiura & $15 \%$
\end{tabular}

\begin{tabular}{l|l} 
Cranaon cranaon & $15 \%$ \\
\hline Mediomastus fraailis & $15 \%$ \\
\hline
\end{tabular}

\begin{tabular}{l|l} 
Mediomastus fraailis & $15 \%$ \\
\hline Eumida & $15 \%$
\end{tabular}

Crepidula fornicata

Phtisica marina

Phyllodocidae

Abra

Malmarenia darboux

Veneridae

Mvtilus edulis

Gastrosaccus spinifer

Achelia echinata

Ensis leei

Asterias rubens

Magelona

Eteone

Venerupis corruqata

Microphthalmus

Heteromastus filiformis

Nereididae

Myrianida

Spio

Corophiidae

Terebellidae

Autolytinae

Magelona mirabilis

Ophiura albida

Owenia fusiformis

Pontocrates altamarinus

Monocorophium acherusicum
(2)

(2)

(n)

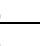

-

$\%$

$\%$

$\%$

$\%$

$\%$

$\%$

$\%$

\%

$4 \%$

$14 \%$

$4 \%$

$3 \%$

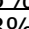

(3\%

$3 \%$

$3 \%$

$2 \%$

$12 \%$

$1 \%$

$1 \%$

$\%$

$1 \%$

$11 \%$

$11 \%$

$11 \%$

$11 \%$

$10 \%$

$10 \%$

$10 \%$ 
Tabel 2: Statistische waarden voor het aantal taxa en de voorkomingsfrequentie van soorten berekend op basis van de Voordelta gegevens (PMR-NCV 2004-2017) op locaties dieper dan 20m ( $n=224$ locaties).

\section{Voordelta}

\section{Aantal taxa}

\section{Voorkomingsfrequentie taxa}

71 taxa in $5 \%$ van de monsters samengevoegd tot 0 taxa in meer dan $90 \%$ van de monsters een monsteroppervlak van $0,78 \mathrm{~m}^{2}$

5 taxa in 50 tot $90 \%$ van de monsters

46 taxa in 10 tot $50 \%$ van de monsters

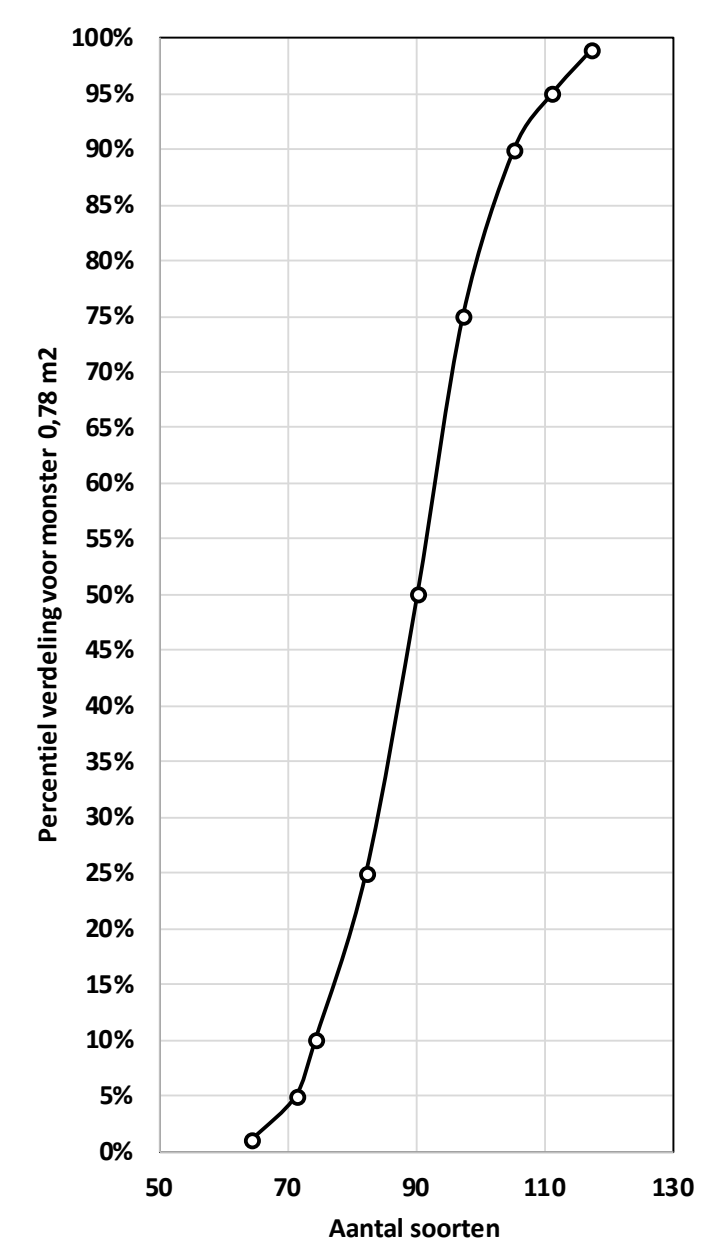

Soort $\quad$ Frequentie

Spiophanes bombvx $\quad 71 \%$

Nephtvs cirrosa $\quad 60 \%$

Nemertea $\quad 59 \%$

\begin{tabular}{l|l} 
Urothoe poseidonis & $56 \%$ \\
\hline
\end{tabular}

Echinocardium cordatum $\quad 55 \%$

\begin{tabular}{ll} 
Eteone & $48 \%$ \\
\hline Tellimva ferruainosa & $45 \%$
\end{tabular}

\begin{tabular}{l|l} 
Tellimva ferruqinosa & $45 \%$ \\
\hline
\end{tabular}

Scoloplos $40 \%$

$\begin{array}{ll}\text { Nephtvs } & 40 \%\end{array}$

Abra alba $38 \%$

Ensis directus $\quad 38 \%$

Kurtiella bidentata $37 \%$

Fabulina fabula $\quad 36 \%$

Oliaochaeta $36 \%$

Heteromastus filiformis $\quad 35 \%$

Poecilochaetus serpens $\quad 34 \%$

Eunereis lonaissima $\quad 34 \%$

Notomastus latericeus $\quad 34 \%$

$\begin{array}{ll}\text { Nephtvs homberaii } & 32 \%\end{array}$

Leucothoe incisa $32 \%$

Actiniaria $30 \%$

\begin{tabular}{l|l} 
Eumida & $27 \%$ \\
\hline
\end{tabular}

Phoronidae $25 \%$

Owenia fusiformis $\quad 24 \%$

\begin{tabular}{ll} 
Ensis & $23 \%$ \\
\hline Scoloplos armiger & $23 \%$
\end{tabular}

\begin{tabular}{l} 
Scoloplos armiaer \\
\hline Phyllodoce mucosa
\end{tabular}

Maqelona iohnstoni

Abludomelita obtusata $19 \%$

Ophiura albida

Ophiura ophiura

Phoronida

Laqis koreni

Pestarella tyrrhena

Malmarenia Iunulata

Magelona papillicornis

Processa parva

Mediomastus fraqilis $14 \%$

\begin{tabular}{ll} 
Capitella capitata & $14 \%$ \\
\hline Spio martinensis & $13 \%$
\end{tabular}

\begin{tabular}{l|l} 
Spio martinensis & $13 \%$ \\
\hline Spio & $13 \%$
\end{tabular}

$13 \%$

$\begin{array}{ll}\text { Tellinoidea } & 12 \%\end{array}$

Caprellidae

Maqelona mirabilis

Gastrosaccus spinifer

$12 \%$

$11 \%$

$\begin{array}{ll}\text { Phyllodoce } & 10 \%\end{array}$

\begin{tabular}{ll} 
Nereis & $10 \%$ \\
\hline
\end{tabular}

Bathvporeia quilliamsoniana $10 \%$

Urothoe brevicornis $10 \%$ 


\subsection{Algemene omschrijving bodemmonsters}

De meeste bodemmonsters worden gekenmerkt door de aanwezigheid van gruis, stenen, mosselpeulen, oude (fossiele) schelpen, en soms klei (zie Bijlages $1 \mathrm{t} / \mathrm{m} 4$ ). De bodem is vaak hard en daardoor moeilijk te bemonsteren. De mediane korrelgrootte van de zandfractie varieert tussen 130 en $534 \mu \mathrm{m}$, en het zand kan omschreven worden als zeer fijn zand tot uiterst grof zand (Bijlage 11). Het uiterst grof zand komt voor bij Roompot Oost; het zeer fijn / matig fijn zand vooral bij Schaar Oost.

\subsection{Benthosgemeenschappen in huidige monitoring}

In totaal zijn er 132 taxa onderscheiden in de 20 onderzochte locaties, waarvan 43 taxa slechts voorkomen in één monster en 30 in $>50 \%$ van de monsters (Tabel 3). Slangsterren (Ophiura spp.) zijn in elk monster aangetroffen; zeeanemonen (Actiniaria), de vlokreeft Abludomelita obtusata, de borstelwormen Glycera tridactyla en Phyllodoce mucosa komen voor in meer dan $80 \%$ van de monsters. De meest voorkomende tweekleppige betreft de witte dunschaal Abra alba gevonden in $70 \%$ van de monsters. In de negen monsters aan de Oosterscheldezijde van de kering en in de elf monsters aan de Voordeltazijde werden respectievelijk 95 en 98 taxa aangetroffen.

Het aantal taxa per monster varieert tussen 13 en 57, met een gemiddelde van 35,9 2,5(se) taxa per monster.

Tabel 3: Lijst met meest voorkomende (in $\min .50 \%$ van de monsters) taxa in deze studie. $N=20$.

\begin{tabular}{|c|c|c|c|}
\hline Taxon name & Phylum & Voorkomen (n) & Voorkomen (\%) \\
\hline Ophiura spp. & Echinodermata & 20 & 100 \\
\hline Actiniaria & Cnidaria & 19 & 95 \\
\hline Abludomelita obtusata & Arthropoda & 17 & 85 \\
\hline Glycera tridactyla & Annelida & 17 & 85 \\
\hline Phyllodoce mucosa & Annelida & 17 & 85 \\
\hline Asterias rubens & Echinodermata & 16 & 80 \\
\hline Mediomastus spp. & Annelida & 16 & 80 \\
\hline Nemertea & Nemertea & 16 & 80 \\
\hline Clitellata (Oligochaeta) & Annelida & 16 & 80 \\
\hline Aora typica & Arthropoda & 15 & 75 \\
\hline Abra alba & Mollusca & 14 & 70 \\
\hline Bodotria scorpioedes & Arthropoda & 14 & 70 \\
\hline Lanice conchilega & Annelida & 14 & 70 \\
\hline Sthenelais boa & Annelida & 14 & 70 \\
\hline Eunereis longissima & Annelida & 13 & 65 \\
\hline Mytilus edulis & Mollusca & 13 & 65 \\
\hline Syllidia armata & Annelida & 13 & 65 \\
\hline Capitella spp. & Annelida & 12 & 60 \\
\hline Caprellidae & Arthropoda & 12 & 60 \\
\hline Myrianida spp. & Annelida & 12 & 60 \\
\hline Notomastus latericeus & Annelida & 12 & 60 \\
\hline Pisidia longicornis & Arthropoda & 12 & 60 \\
\hline Achelia echinata & Arthropoda & 11 & 55 \\
\hline Eumida sanguinea & Annelida & 11 & 55 \\
\hline Kurtiella bidentata & Mollusca & 11 & 55 \\
\hline Lysianassa ceratina & Arthropoda & 11 & 55 \\
\hline Ophiothrix fragilis & Echinodermata & 11 & 55 \\
\hline Ophiothrix spp. & Echinodermata & 11 & 55 \\
\hline Pholoe balthica & Annelida & 10 & 50 \\
\hline Sabella pavonina & Annelida & 10 & 50 \\
\hline
\end{tabular}


De quickscan van de overige 16 monsters laat eenzelfde dominantie van soorten zien (Bijlage 10). Meest algemene soorten in de quickscan zijn de vlokreeft Abludomelita obtusata, slangsterren (Ophiura spp.), zeeanemonen (Actiniaria), de borstelworm Glycera tridactyla, en Nemertea en Clitellata (Oligochaeta).

De dichtheid per monster varieert sterk, van 361 ind. $\mathrm{m}^{-2}$ (station HW-07) tot 208.606 ind. $\mathrm{m}^{-2}$ (station HW-03) (Tabel 4). De gemiddelde dichtheid bedraagt $45.196 \pm 10.106$ (se) ind. $\mathrm{m}^{-2}$. Er wordt een duidelijke positieve relatie gevonden tussen het aantal taxa en de dichtheid.

Net als de dichtheid varieert de biomassa sterk, van 0,6 g AFDW.m-2 (station HW-07) tot 221,9 g AFDW.m-2 (station HW-04). De gemiddelde biomassa bedraagt 74,6 $\pm 14,4$ (se) g AFDW.m ${ }^{-2}$.

Tabel 4: Aantal taxa en dichtheid per monster.

\begin{tabular}{|c|c|c|c|c|c|}
\hline LOKCODE & OMSCHRIJVING & GEBIED & $\begin{array}{c}\text { Aantal taxa } \\
\text { (n) }\end{array}$ & $\begin{array}{l}\text { Dichtheid } \\
\left(\text { ind. } m^{-2}\right)\end{array}$ & $\begin{array}{c}\text { Biomassa } \\
\left(g_{\text {AFDW. }} \mathrm{m}^{-2}\right)\end{array}$ \\
\hline 19-OK-HO-02 & Hammen Oost & Oosterschelde & 34 & 5.744 & 33,0 \\
\hline 19-OK-HO-03 & Hammen Oost & Oosterschelde & 37 & 7.756 & 19,3 \\
\hline 19-OK-HO-06 & Hammen Oost & Oosterschelde & 33 & 5.721 & 4,7 \\
\hline 19-OK-RO-01 & Roompot Oost & Oosterschelde & 46 & 6.654 & 19,0 \\
\hline 19-OK-RO-02 & Roompot Oost & Oosterschelde & 38 & 4.103 & 133,2 \\
\hline 19-OK-RO-06 & Roompot Oost & Oosterschelde & 42 & 10.090 & 75,4 \\
\hline 19-OK-SO-01 & Schaar Oost & Oosterschelde & 39 & 17.013 & 70,7 \\
\hline 19-OK-SO-02 & Schaar Oost & Oosterschelde & 41 & 6.923 & 66,0 \\
\hline 19-OK-SO-04 & Schaar Oost & Oosterschelde & 45 & 8.795 & 120,5 \\
\hline 19-OK-HW-03 & Hammen West & Voordelta & 26 & 3.705 & 71,4 \\
\hline 19-OK-HW-04 & Hammen West & Voordelta & 44 & 208.606 & 221,9 \\
\hline 19-OK-HW-07 & Hammen West & Voordelta & 13 & 361 & 0,6 \\
\hline 19-OK-RW1-01 & Roompot West 1 & Voordelta & 13 & 359 & 4,3 \\
\hline 19-OK-RW1-04 & Roompot West 1 & Voordelta & 45 & 13.923 & 80,6 \\
\hline 19-OK-RW2-01 & Roompot West 2 & Voordelta & 35 & 11.051 & 163,0 \\
\hline 19-OK-RW2-03 & Roompot West 2 & Voordelta & 35 & 8.615 & 196,2 \\
\hline 19-OK-SW1-02 & Schaar West 1 & Voordelta & 57 & 17.167 & 66,0 \\
\hline 19-OK-SW1-03 & Schaar West 1 & Voordelta & 44 & 19.641 & 71,3 \\
\hline 19-OK-SW2-03 & Schaar West 2 & Voordelta & 18 & 474 & 2,5 \\
\hline 19-OK-SW2-04 & Schaar West 2 & Voordelta & 33 & 4.179 & 71,4 \\
\hline
\end{tabular}

De meeste taxa komen gemiddeld in zeer lage dichtheden voor: 86 taxa (65\%) hebben een dichtheid lager dan 10 ind. $\mathrm{m}^{-2}$. Het meest voorkomende taxon is Clitellata (Oligochaeta) met gemiddeld 11.763 ind. $\mathrm{m}^{-2}$. Dit komt deels door één monster (station HW-03) met een dichtheid van 182.923 ind. $\mathrm{m}^{-2}$. Maar ook zonder dit monster zijn Clitellata nog steeds het meest abundante taxon met gemiddeld 2.616 ind. $\mathrm{m}^{-2}$. Andere taxa die in relatief grote aantallen voorkomen zijn de borstelworm Mediomastus spp. (gemiddeld 1.004 ind. $\mathrm{m}^{-2}$ ), slangsterren (Ophiura spp. 758 ind. $\mathrm{m}^{-2}$, Ophiothrix fragilis 267 ind. $\mathrm{m}^{-2}$, en Ophiothrix spp. 133 ind. $\mathrm{m}^{-2}$ ), de vlokreeften Abludomelita obtusata (666 ind. $\mathrm{m}^{-2}$ ) en Aora typica (140 ind. $\mathrm{m}^{-2}$ ), zeeaneomen Actiniaria (492 ind. $\mathrm{m}^{-2}$ ), Nemertea (190 ind. $\mathrm{m}^{-2}$ ), de schelpkokerworm Lanice conchilega (185 ind. $\mathrm{m}^{-2}$ ), de witte boormossel Barnea candida (164 ind. $\mathrm{m}^{-2}$, vooral in één monster hoge densiteit), en de borstelworm Eumida sanguinea (102 ind. $\mathrm{m}^{-2}$ ). Alle overige taxa komen in een dichtheid lager dan 100 ind. $\mathrm{m}^{-2}$ voor.

De bodemdierenbiomassa wordt gedomineerd door de brokkelster Ophiothrix fragilis (24,3 g AFDW.m ${ }^{-2}$ gemiddeld), de zeeanemonen Actiniaria (22.3 g AFDW. $\left.\mathrm{m}^{-2}\right)$, de gewone zeester Asterias rubens $(9,3 \mathrm{~g}$ AFDW. $\left.\mathrm{m}^{-2}\right)$, de schelpkokerwormen Sabella pavonina $\left(4,7 \mathrm{~g}\right.$ AFDW. $\left.{ }^{-2}\right)$ en Lanice conchilega $(3,6 \mathrm{~g}$ AFDW. $\mathrm{m}^{-2}$ ) en de witte boormossel Barnea candida (2,7 g AFDW. $\mathrm{m}^{-2}$ ). De overige taxa komen gemiddeld voor met een biomassa lager dan $1 \mathrm{~g}$ AFDW. $\mathrm{m}^{-2}$. 


\subsection{Vergelijking met referentiewaarden}

\subsubsection{Mate van overeenkomst met Natura 2000-habitat soortenlijsten}

Tabel 5 toont de lijst met 18 soorten die opgenomen zijn in de profieldocumenten (zie Bijlage 7 en Bijlage 8) en welke hiervan zijn aangetroffen in dit onderzoek. Van de 18 soorten, komen er 13 voor in deze studie. Aan de Oosterschelde zijde zijn 4 van de 9 soorten aangetroffen in de Oosterschelde locaties. De borstelworm Nephtys hombergii en de vlokreeft Urothoe poseidonis, kwalificerende soorten voor de Oosterschelde, komen enkel voor aan de buitenkant (Voordelta) van de Oosterscheldekering. In de soortenlijst van de Oosterschelde staat een aantal soorten die meer typisch zijn voor droogvallende intergetijdengebieden of ondiepe sublitorale gebieden, zoals de wadpier Arenicola marina, de zeeduizendpoot Hediste diversicolor en de kokkel Cerastoderma edule. De aanwezigheid van deze soorten is zeer onwaarschijnlijk in de diepe en zeer dynamische ontgrondingskuilen. Dat wordt bevestigd door de afwezigheid van deze soorten in de huidige monitoring. Vrijwel alle soorten in soortenlijst van de Voordelta worden aangetroffen in de Voordelta, op Echinocardium cordatum en Bathyporeia elegans na. Ook in de quickscan van de overige 16 monsters worden Natura 2000-habitat soorten aangetroffen: Ophiura sp., Actinaria, Lanice conchilega, Carcinus maenas, Liocarcinus sp., Mytilus edulis, en Nephtys sp. (Bijlage 10). Deze zijn echter niet steeds tot op soortniveau gedetermineerd.

Tabel 5: Natura 2000-habitat soortenlijst voor Oosterschelde (OS, geel-groen) en Voordelta (VD, groenblauw) en welke hiervan zijn aangetroffen in deze studie (aangeduid met $\mathbf{x}$ ). Opmerking: (1) in profiefdocument OS staat Metridium senile (zeeanjelier, Actinaria)). In deze studie zijn Actinaria niet op soort gebracht, en staat daarom als Orde Actinaria vermeld. (2) In profieldocument VD staat Ophiura ophiura, in deze studie 1x aangetroffen, overige Ophiura ind. niet tot op soort gebracht. (3) (x): Nepthys sp. wel aangetroffen in de quickscan monsters (zie Bijlage 6).

\begin{tabular}{|l|c|c|}
\hline Taxon & Oosterschelde & Voordelta \\
\hline Actiniaria (OS) & $\boldsymbol{x}$ & $\boldsymbol{x}$ \\
\hline Arenicola marina (OS) & & $\boldsymbol{x}$ \\
\hline Nephtys hombergii (OS) & & $\boldsymbol{x}$ \\
\hline Hediste (Nereis) diversicolor (OS) & & $\boldsymbol{x}$ \\
\hline Carcinus maenas (OS) & $\boldsymbol{x}$ & $\boldsymbol{x}$ \\
\hline Cerastoderma edule (OS) & $\boldsymbol{x}$ & $\boldsymbol{x}$ \\
\hline Mytilus edulis (OS) & & $\boldsymbol{x}$ \\
\hline Lanice conchilega (OS + VD) & & $\boldsymbol{x}$ \\
\hline Urothoe poseidonis (OS + VD) & & $\boldsymbol{x}$ \\
\hline Echinocardium cordatum (VD) & & $\boldsymbol{x}$ \\
\hline Spiophanes bombyx (VD) & & $\boldsymbol{x}$ \\
\hline Nephtys cirrosa (VD) & & $\boldsymbol{x}$ \\
\hline Magelona papillicornis (VD) & $\boldsymbol{x}$ \\
\hline Bathyporeia elegans (VD) & & $\boldsymbol{x}$ \\
\hline Liocarcinus holsatus (VD) & & \\
\hline Pagurus bernhardus (VD) & & \\
\hline Pontocrates altamarinus (VD) & & \\
\hline Ophiura spp. (VD) & & \\
\hline
\end{tabular}

\subsubsection{Mate van overeenkomst met soortenrijkdom monitoringsprogramma's}

In totaal zijn 95 taxa waargenomen in de monsters aan de Oosterschelde zijde van de kering, en 98 taxa aan de Voordelta zijde. Deze waarden van soortenrijkdom zijn ruim boven de $5^{\text {de }}$ percentielen van de verdeling gevonden voor de referentie datasets MWTL (73 taxa) en PMR-NCV (71 taxa) voor een overeenkomend monsteroppervlak van 0,78 $\mathrm{m}^{2}$ (10 monsters). De waargenomen waarden van 95 en 98 taxa komen overeen met respectievelijk de $22^{\text {ste }}$ en $76^{\text {ste }}$ percentielen van de verdeling berekend op basis van de MWTL en PMR-NCV monitoringsgegevens. 


\subsubsection{Mate van overeenkomst met soortensamenstelling monitoringsprogramma's}

Een groot aantal taxa die frequent in het MWTL monitoringsprogramma van de Oosterschelde (ecotoop hoogdynamisch sublitoraal) voorkomen, worden ook in deze studie aangetroffen, zij het dat de frequentie van voorkomen vaak verschilt (Bijlage 8). Sommige taxa die in de MWTL lijst op het niveau van familie of genus voorkomen, zijn in deze studie tot op het niveau van soort op naam gebracht, wat een directe vergelijking niet altijd mogelijk maakt. In het MWTL monitoringprogramma wordt vooral een aantal borstelwormen frequent waargenomen, waaronder de wapenworm Scoloplos armiger, zandzagers (Nephtys sp., Nephtys cirrosa, Nepthys hombergii), noordelijke zandkokerworm Spiophanes bombyx en Magelona johnstoni. Deze soorten komen echter niet tot nauwelijks voor in de ontgrondingskuilen. Deze soorten zijn inderdaad karakteristiek voor zandige sedimenten en lijken dus in de bodems van de ontgrondingskuilen, met veel schelpen, gruis en stenen, geen geschikt habitat te vinden. Aan de andere kant komt een aantal epibentische soorten (i.e. soorten die op i.p.v. in de bodem leven) zoals zeeanemonen (Actiniaria), brokkelsterren (Ophiura, Ophiothrix), zeesterren (Asterias rubens) veel frequenter voor in de ontgrondingskuilen dan in het MWTL monitoringsprogramma. Ook kokerwormen zoals Lanice conchilega en Sabella pavonina en een aantal kleinere borstelwormen zijn vaker aangetroffen in huidig dan in het MWTL monitoringsprogramma van de Oosterschelde (ecotoop hoogdynamisch sublitoraal).

In de referentiedataset van het MWTL monitoringsprogramma komt slechts één soort (Scoloplos armiger) voor in meer dan $90 \%$ van de monsters, drie taxa zijn aangetroffen in $50 \%$ tot $90 \%$ van de monsters en 69 taxa in $10 \%$ tot $50 \%$ van de monsters (Tabel 1). Vervolgens, op basis van de trefkansfuncties weergegeven in Figuur 6, zouden 11 taxa uit de 10-50\% lijsten aangetroffen moeten worden in de huidige monitoring, terwijl de afwezigheid van de soorten uit de $>90 \%$ en $50 \%-90 \%$ lijsten wel toelaatbaar zou zijn om te kunnen voldoen aan de hypothese van conformiteit met de gegevens uit het MWTL monitoringsprogramma. Er worden echter meer taxa waargenomen in het huidig onderzoek aan de binnenkant van de Oosterscheldekering (OS), met respectievelijk 1, 1 en 37 taxa uit de $>90 \%$ $50 \%-90 \%$ en $10-50 \%$ MWTL lijsten (Bijlage 9 ).

Een groot aantal taxa dat frequent in het PMR-NCV monitoringsprogramma in de Voordelta is aangetroffen, wordt ook in deze studie aangetroffen, zij het dat de frequentie van voorkomen verschilt (Bijlage 10). Net als aan de binnenkant van de kering, komen zandzagers in de ontgrondingskuilen aan de buitenkant van de kering minder frequent voor dan in de Voordelta. Daarnaast valt de afwezigheid op van de zeeklit Echinocardium cordatum en van de ovale zeeklitschelp Tellimya feryginosa. De zeeklit zit ingegraven in zandige bodems, met de ovale zeeklitschelp vaak voorkomend in de gangen van de zeeklit. Het habitat bij de ontgrondingskuilen is voor deze soorten zeer waarschijnlijk niet geschikt. Een aantal epibentische soorten, zoals zeeanemonen (Actiniaria), brokkelsterren (Ophiura, Ophiothrix), zeesterren (Asterias rubens), komen frequenter voor in de ontgrondingskuilen.

In de gegevens van het PMR-NCV monitoringsprogramma komt geen soort voor in meer dan $90 \%$ van de monsters, 5 taxa zijn aangetroffen in 50 tot $90 \%$ van de monsters en 46 taxa in $10 \%$ tot $50 \%$ van de monsters (Tabel 2). Vervolgens, op basis van de trefkansfuncties weergegeven in Figuur 6, zouden respectievelijk 1 en 7 taxa uit de 50\%-90\% en $10-50 \%$ lijsten aangetroffen moeten worden, terwijl de afwezigheid van de soorten uit de $>90 \%$ lijst wel toelaatbaar zou zijn om te voldoen aan de hypothese van conformiteit tussen de huidige monitoring en de locaties uit het PMR monitoringsprogramma. Er worden echter meer taxa waargenomen in het huidig onderzoek aan de buitenkant van de Oosterscheldekering (VD), met respectievelijk 4 en 32 taxa gevonden uit de 50\%-90\% en 10-50\% PMRNCV lijsten (Bijlage 9).

In totaal zijn 132 taxa onderscheiden in de 20 onderzochte monsters; 95 taxa zijn waargenomen in de monsters aan de Oosterscheldezijde van de kering, en 98 taxa aan de Voordeltazijde. In vergelijking met de MWTL en PMR-NCV

. monitoringsprogramma's behoren de waargenomen waarden van soortenrijkdom tot representatieve niveaus voor respectievelijk de Oosterschelde en de Voordelta. 
De vraag die middels deze studie beantwoord diende te worden, luidde: kunnen de ontgrondingskuilen nabij de Oosterscheldekering aangemerkt worden als kwalitatief goed habitattype, zoals wettelijk zijn aangewezen in deze Natura 2000-gebieden? Om deze vraag te kunnen beantwoorden, is rondom de kering een bodemdierbemonstering uitgevoerd. Verwacht werd dat het habitat ter plaatse van het te bestorten gebied weinig ecologische waarde heeft doordat de hoge dynamiek rond de kering de kans op vestiging van soorten moeilijk maakt.

De bemonstering van de bodem van de ontgrondingskuilen met een boxcorer bleek niet eenvoudig te zijn. In tegenstelling tot de verwachting van een homogene zandige bodem, eventueel met hier en daar wat stenen afkomstig van eerdere bestortingen, bleek de samenstelling van de bodem veelal te bestaan uit een mengeling van gruis, stenen, fossiele schelpen, en mosselpeulen. De bodem bleek veelal een heterogene samenstelling te hebben, met grote verschillen tussen de bemonsterde stations. De aanwezigheid van vaak harde substraten, tezamen met de grote diepte en hoge stroomsnelheden, zorgden voor bodemmonsters van onvoldoende hapdiepte $(15 \mathrm{~cm})$. Toch zijn 32 locaties bemonsterd, waarbij een aantal van de voorziene locaties wegens omstandigheden verlegd dienden te worden. De meeste monsters omvatten een groot volume, wat wegens logistieke redenen tot een aanpassing van het aantal uitgezochte monsters heeft geleid (20 i.p.v. 36). Ook de verwerking van de monsters werd aangepast, waarbij is gezocht naar een evenwicht tussen efficiëntie en voldoende nauwkeurigheid om de onderzoeksvraag te kunnen beantwoorden. Sommige monsters bleken erg bewerkelijk, met veel schelpengruis, maar ook veel Hydrozoa en tentakels van Lanice conchilega. Hiertussen kunnen kleine individuen van wormen, schelpdieren, slang-/brokkelsterren en andere taxa ongezien achterblijven.

In totaal zijn 132 taxa onderscheiden in de 20 onderzochte monsters; 95 taxa zijn waargenomen in de monsters aan de Oosterscheldezijde van de kering, en 98 taxa aan de Voordeltazijde. In vergelijking met de MWTL en PMR-NCV monitoringsprogramma's behoren de waargenomen waarden van soortenrijkdom tot representatieve niveaus voor respectievelijk de Oosterschelde en de Voordelta.

Verschillende typische soorten van het habitattype H1160 (OS, grote baaien) en H1110 (VD, permanent overstroomde zandbanken) zijn in de ontgrondingskuilen waargenomen. Vergeleken met het habitattype H1160 ontbreekt aan de Oosterscheldezijde van de kering de helft van het totaal aantal soorten, maar dit zijn eerder soorten van intergetijdengebieden en ondiepe sublitorale gebieden zoals de kokkel, zeeduizendpoot en wadpier. Vergeleken met het habitattype H1110 ontbreken aan de Voordeltazijde van de kering de zeeklit en de, vaak met de zeeklit geassocieerde, ovale zeeklitschelp. Deze organismen leven ingegraven in zandige tot slibrijke bodems, terwijl de ontgrondingskuilen eerder bestaan uit grovere bodems met gruis, schelpen en stenen. De bodemdiergemeenschap in de ontgrondingskuilen is zeer gevarieerd, en de monsters variëren sterk in zowel het aantal taxa, de densiteit en de biomassa, met een aantal zeer rijke monsters met hoge aantallen en biomassa. Opvallend is de dominantie van een aantal epibentische soorten zoals zeeanemonen (Actiniaria), brokkelsterren (Ophiura, Ophiothrix), en zeesterren (Asterias rubens) die op de grovere bodem een geschikt habitat aantreffen. Daarnaast valt de aanwezigheid van kokerwormen op, zoals de schelpkokerworm Lanice conchilega en de pauwenstaart-viltkokerworm Sabella pavonina. De witte boormossel werd op één locatie, ingeboord in verharde klei, in hoge dichtheden en biomassa aangetroffen. In deze grovere bodems komen daarnaast kleine soorten wormen voor, zoals Oligochaeta en Mediomastus sp. Meerdere soorten die frequent in reguliere en lopende monitoringsprogramma's (MWTL Oosterschelde, PMR-NCV Voordelta) worden waargenomen, worden ook in de ontgrondingskuilen aangetroffen. Echter, de verschillen in frequentie van voorkomen en de afwezigheid van sommige soorten wijzen op een typische gemeenschap in de ontgrondingskuilen. De monitoringsprogramma's dekken uiteraard een veel groter gebied, met meerdere (sub)habitats. De ontgrondingskuilen kunnen, met hun dynamisch karakter en grove bodems met gruis, schelpen en stenen, beschouwd worden als één van deze sub(habitats) met een eigen, kenmerkende bodemdiergemeenschap. 
Terugkomend op de onderzoeksvraag, kan er gesteld worden dat de huidige locaties van de ontgrondingskuilen uiteenlopende habitats tonen met, lokaal, hoge soortenrijkdom, aantallen en biomassa's aan bodemdieren en met verschillende soorten die als typische soorten kwalificeren binnen de Natura 2000-habitats H1160 en H1110. Ook in de meest soortenarme stations (HW-04 en RW1-01) komen kwalificerende soorten zoals de zandzager Nephtys cirrosa voor.

De ontgrondingskuilen herbergen een typische bodemdiergemeenschap, horende bij dit dynamische milieu. Ondanks de hoogdynamische omstandigheden, kunnen verschillende soorten zich vestigen in deze grovere bodems, zowel epibenthische soorten als soorten die genieten van de bescherming van een eigen koker (kokerwormen). De kokerwormen bieden daarbij een leefgebied voor heel wat andere, kleinere soorten. Concluderend kan gesteld worden dat de huidige bevindingen niet overeenkomen met de vooropgestelde hypothese dat de ontgrondingskuilen slechts verarmde bodemdiergemeenschappen zonder typische Natura 2000-soorten herbergen. 


\section{$5 \quad$ Kwaliteitsborging}

Wageningen Marine Research beschikt over een ISO 9001:2015 gecertificeerd kwaliteitsmanagementsysteem. Dit certificaat is geldig tot 15 december 2021. De organisatie is gecertificeerd sinds 27 februari 2001. De certificering is uitgevoerd door DNV GL.

Indien sprake is van onbeheerste kwaliteit worden passende maatregelen genomen. 


\section{Literatuur}

Stoutjesdijk, T., De Kleine, M., De Ronde, J., Raaijmakers, T., 2012. Stormvloedkering Oosterschelde: Ontwikkeling ontgrondingskuilen en stabiliteit bodembescherming. Hoofdrapport. Deltares rapport 1206907005-GE0-0004 voor Rijkswaterstaat, Waterdienst.

Van der Woude, E.A., van Schie, F.M., 2019. Passende beoordeling Bestorten Ontgrondingskuilen Oosterscheldekering. Toetsing in het kader van de Wet natuurbescherming (Movares). B85-EWO-KA1900024 / Proj.nr. RM192460. 


\section{Verantwoording}

Rapport C013/20

Projectnummer: 4313100109

Dit rapport is met grote zorgvuldigheid tot stand gekomen. De wetenschappelijke kwaliteit is intern getoetst door een collega-onderzoeker en het verantwoordelijk lid van het managementteam van Wageningen Marine Research

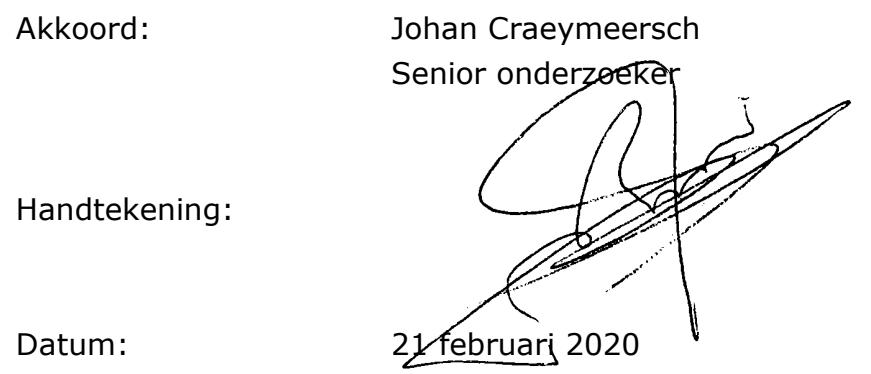

Akkoord: Drs. J. Asjes Manager Integratie)

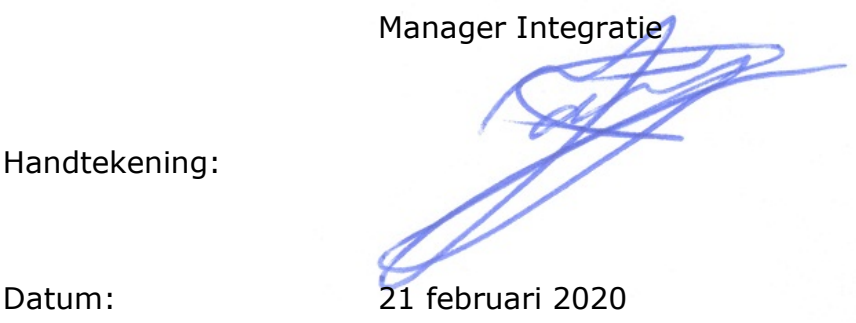




\section{Bijlage 1 Hammenlocaties}

Overzicht van de locaties voor de benthos monstering in de gebieden Hammen West (HW) en Hammen Oost (HO) met als beschrijving de naam van de monsterlocaties (Loc), de datum en tijd, het aantal pogingen $(\#)$, de Noorderbreedte $\left(\mathrm{NB}^{\circ}\right)$ en Oosterlengte $\left(\mathrm{OL}^{\circ}\right)$ coördinaten in graad (WGS84 stelsel), de monsterdiepte in $\mathrm{m}$ (Dpte), de steekdiepte in $\mathrm{cm}$ (Steek) en overige opmerkingen m.b.t. het bodemleven en de bemonstering. Gearceerde rijen staan voor monsters die verplaatst moesten worden.

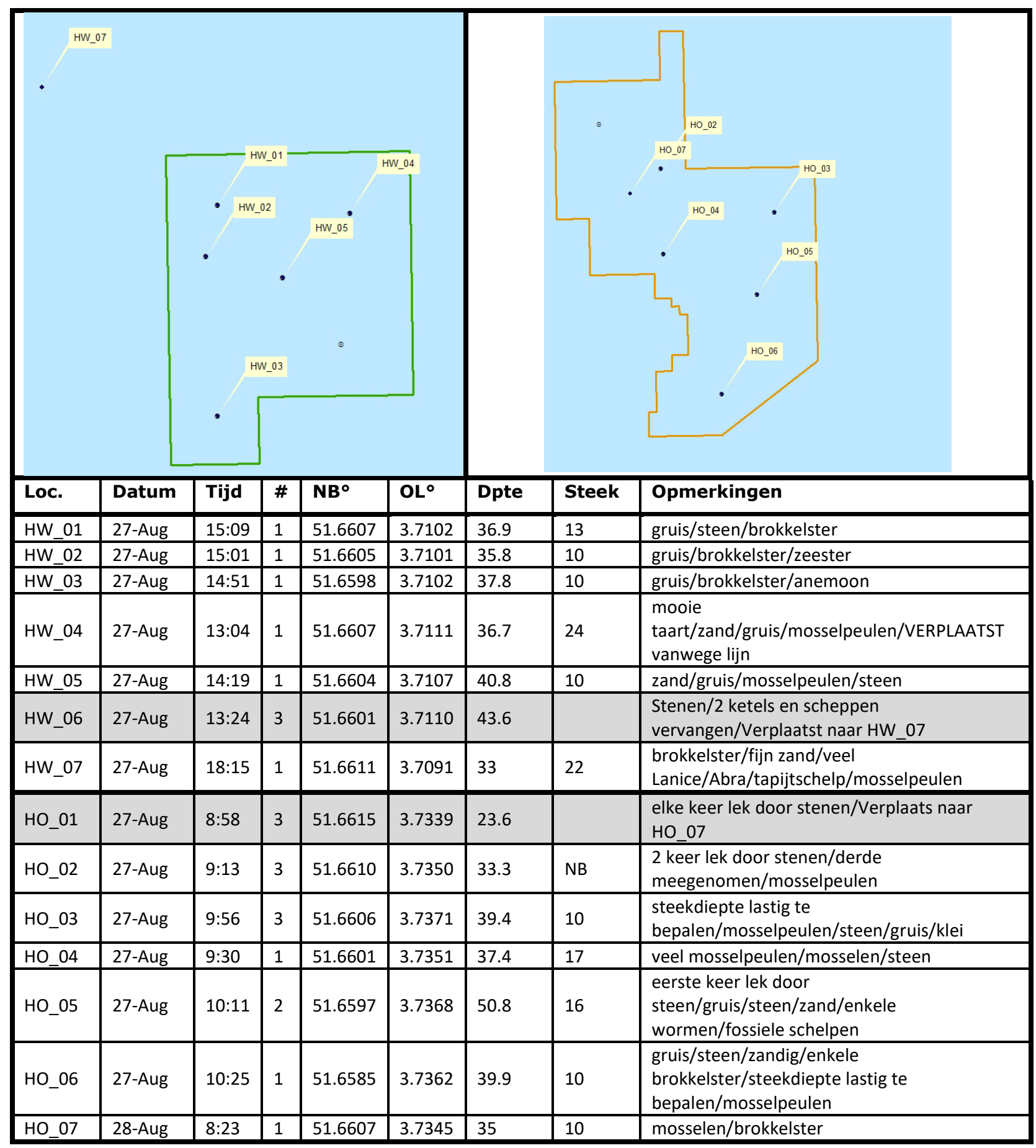




\section{Bijlage 2 Roompotlocaties}

Overzicht van de locaties voor de benthos monstering in de gebieden Roompot West (RW) en Roompot Oost (RO) met als beschrijving de naam van de monsterlocaties (Loc), de datum en tijd, het aantal pogingen (\#), de Noorderbreedte $\left(\mathrm{NB}^{\circ}\right)$ en Oosterlengte $\left(\mathrm{OL}^{\circ}\right)$ coördinaten in graad (WGS84 stelsel), de monsterdiepte in $\mathrm{m}$ (Dpte), de steekdiepte in $\mathrm{cm}$ (Steek) en overige opmerkingen m.b.t. het bodemleven en de bemonstering. Gearceerde rijen staan voor monsters die verplaatst moesten worden.

\begin{tabular}{|c|c|c|c|c|c|c|c|c|}
\hline & & • ${ }^{\mathrm{R}}{ }^{\mathrm{R}}$ & $\prod_{\text {N104 }}^{0.01}$ & & & & - \\
\hline Loc. & $\begin{array}{l}\text { Datu } \\
\text { m }\end{array}$ & Tijd & \# & $\mathbf{N B}^{\circ}$ & $\mathbf{O L}^{\circ}$ & Dpte & Steek & Opmerkingen \\
\hline RW1_01 & 26-Aug & $16: 14$ & 2 & 51.6136 & 3.6710 & 31.3 & 15 & gruis/enkele worm \\
\hline RW1_02 & 26-Aug & $16: 35$ & 3 & 51.6132 & 3.6718 & 40.7 & & $\begin{array}{l}\text { elke lek door steen en klei/Verplaatst naar } \\
\text { RW1_04 }\end{array}$ \\
\hline RW1_03 & 26-Aug & $16: 54$ & 1 & 51.6127 & 3.6712 & 45.2 & 16 & Sabella/mosselpeulen/steen/bagger \\
\hline RW1_04 & 27-Aug & $20: 12$ & 1 & 51.6130 & 3.6713 & 39.9 & 12 & anemoon/mosselpeulen/Sabella/steen/zandig \\
\hline RW2_01 & 26-Aug & $15: 41$ & 1 & 51.6105 & 3.6715 & 44.8 & 15 & brokkelster/steen/anemoon/Abra \\
\hline RW2_02 & 26-Aug & $14: 45$ & 3 & 51.6100 & 3.6731 & 38.6 & & $\begin{array}{l}\text { elke keer lek door steen/Verplaatst naar } \\
\text { RW2_04 }\end{array}$ \\
\hline RW2_03 & 26-Aug & $15: 30$ & 1 & 51.6099 & 3.6717 & 39 & 15 & brokkelster/steen/Abra/wormen \\
\hline RW2_04 & 27-Aug & $20: 27$ & 2 & 51.6102 & 3.6713 & 40.2 & 14 & gruis/anemoon/Abra/brokkelster/steen \\
\hline RO_01 & 26-Aug & $20: 08$ & 1 & 51.6112 & 3.6963 & 53 & NB & gruis/steen/mosselpeulen/enkel zeesterretje \\
\hline RO_02 & 26-Aug & $19: 52$ & 2 & 51.6104 & 3.6978 & 52.4 & 10 & $\begin{array}{l}\text { harde gruisbodem/Sabella/zeester/ } \\
\text { brokkelster }\end{array}$ \\
\hline RO_03 & 26-Aug & 19:30 & 3 & 51.6098 & 3.6965 & 54.4 & 8 & veel gruis/oude schelpen \\
\hline RO_04 & 26-Aug & $19: 14$ & 3 & 51.6098 & 3.6975 & 54.9 & NB & harde gruisbodem /Verplaatst naar RO_07 \\
\hline RO_05 & 26-Aug & 19:01 & 1 & 51.6091 & 3.6970 & 51.1 & 12 & steen/brokkelster/zandig/kleidelen/Sabella \\
\hline RO_06 & 26-Aug & $18: 48$ & 1 & 51.6090 & 3.6954 & 51 & 15 & steen/brokkelster/zandig/kleidelen/Sabella \\
\hline RO_07 & 28-Aug & $11: 40$ & 1 & 51.6105 & 3.6975 & 53.8 & 10 & veel gruis/enkele anemonen/zeester/Sabella \\
\hline
\end{tabular}




\section{Bijlage 3 Schaarlocaties}

Overzicht van de locaties voor de benthos monstering in de gebieden Schaar West (SW) en Schaar Oost (SO) met als beschrijving de naam van de monsterlocaties (Loc), de datum en tijd, het aantal pogingen $(\#)$, de Noorderbreedte $\left(\mathrm{NB}^{\circ}\right)$ en Oosterlengte $\left(\mathrm{OL}^{\circ}\right)$ coördinaten in graad (WGS84 stelsel), de monsterdiepte in $\mathrm{m}$ (Dpte), de steekdiepte in $\mathrm{cm}$ (Steek) en overige opmerkingen m.b.t. het bodemleven en de bemonstering. Gearceerde rijen staan voor monsters die verplaatst moesten worden.

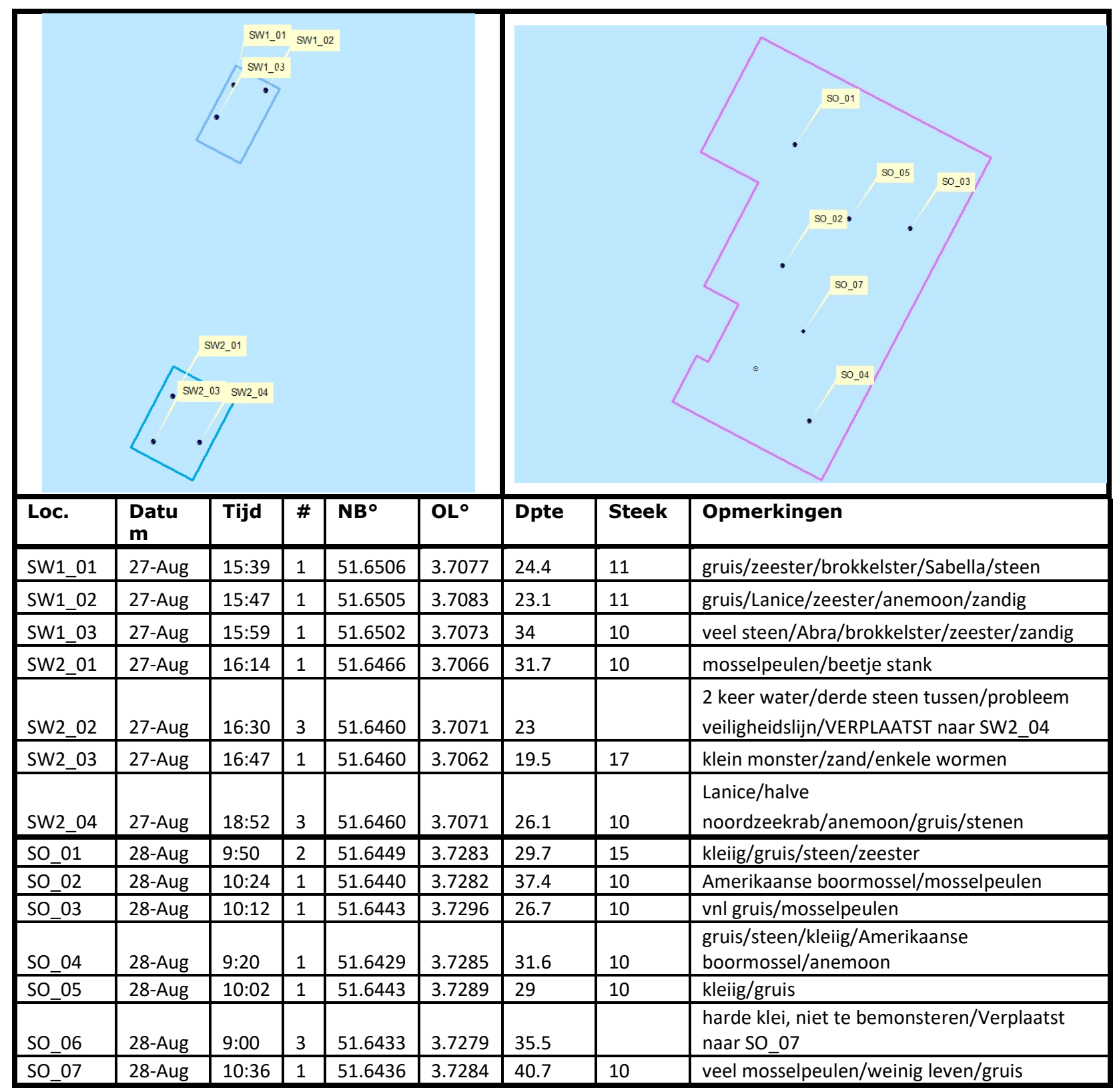




\section{Bijlage 4 Veldwaarnemingen van de monsters, een impressie}

Benthosmonsters ontgrondingskuilen monitoring na het zeven op de $1 \mathrm{~mm}$ zeef aan boord van het schip. Ter referentie, monster HW-03 heeft een omvang van 8 liter, voor SW2-03 is dat 0,5 liter. Bij iedere foto een korte omschrijving van het bodemleven en het type sediment gebaseerd op een eerste indruk van het monster.
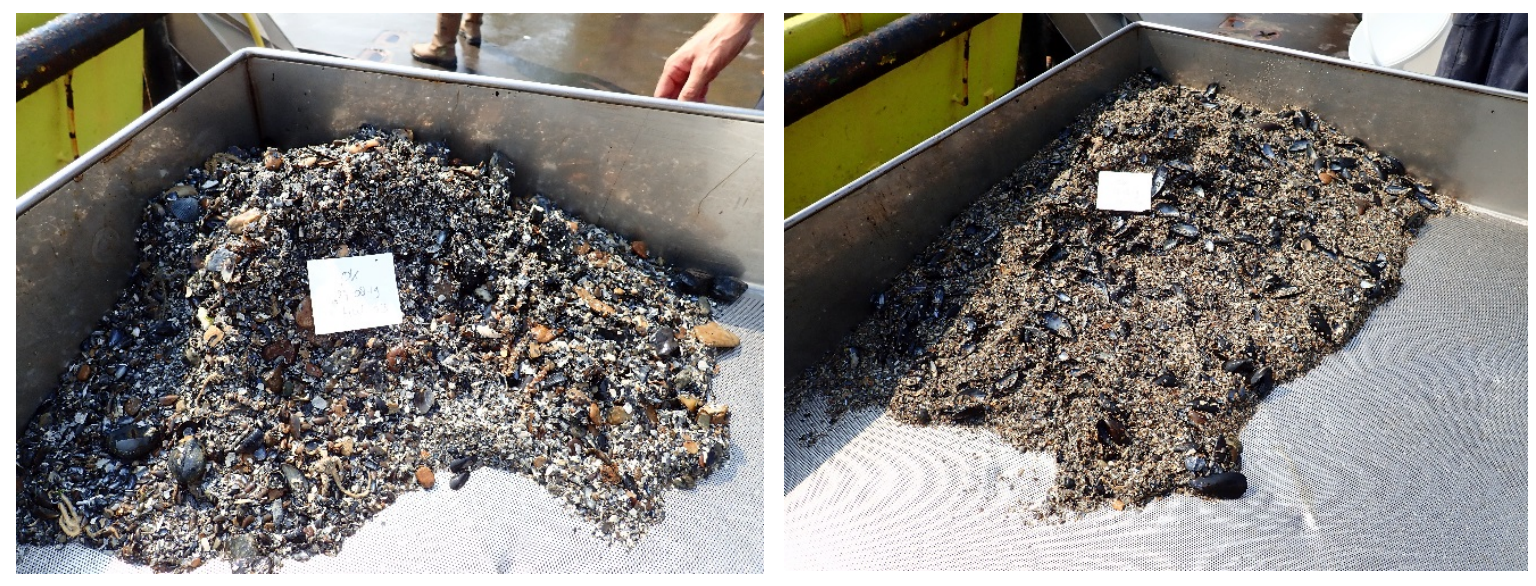

HW-03: veel gruis, brokkelster en anemonen

HW-04: zand en gruis, veel mosselpeulen
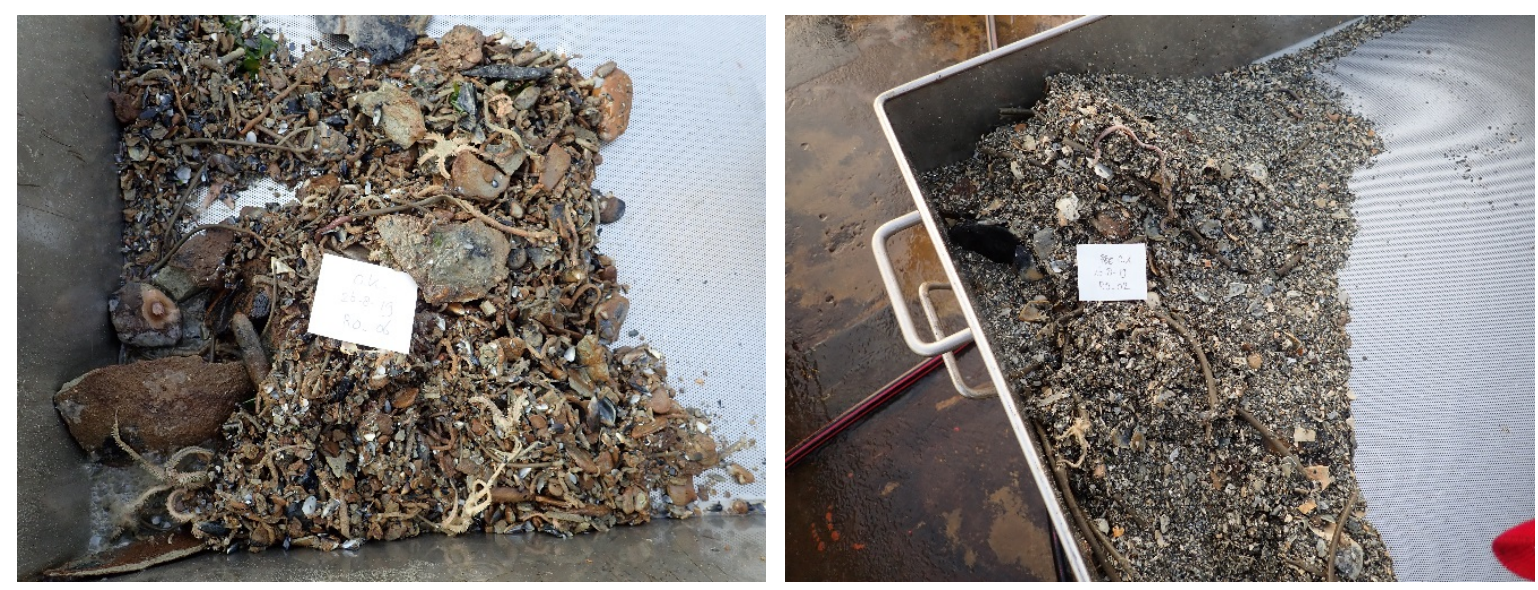

RO-06: zandig met kleidelen, stenen, brokkelster, Sabella

RO-02: harde gruisbodem, Sabella, zeester en brokkelster
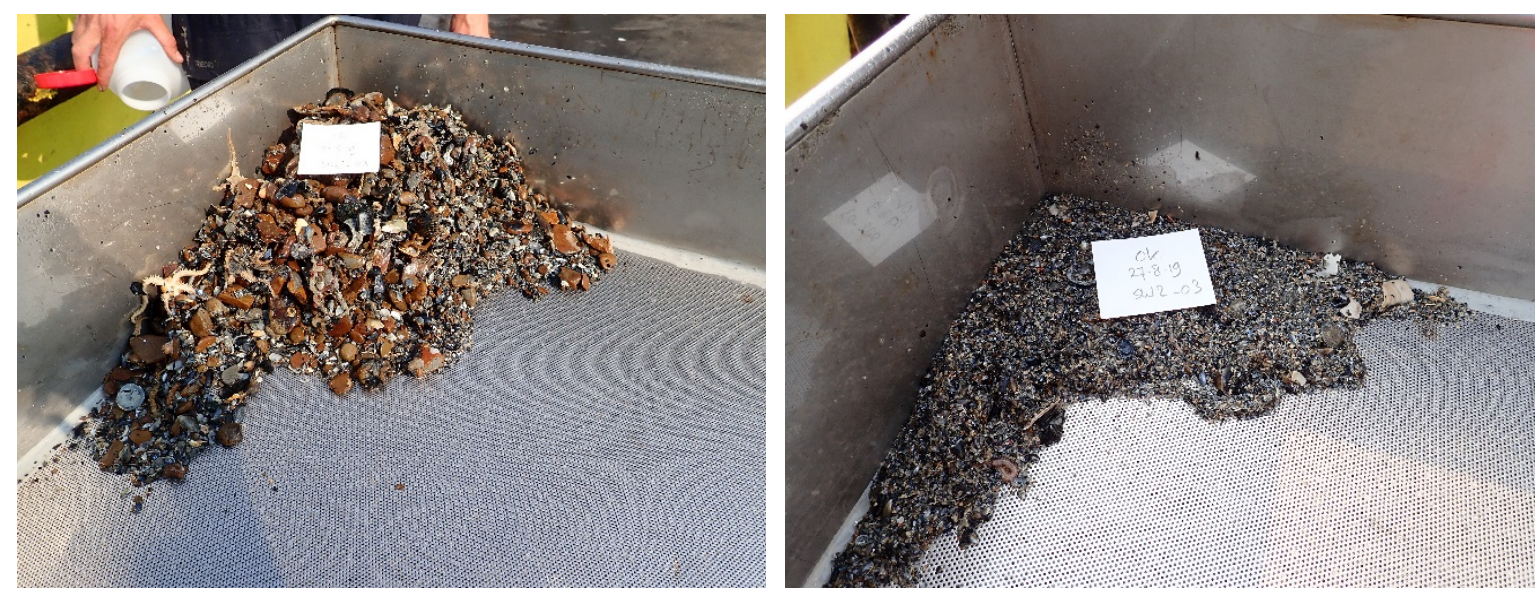

SW1-03: veel stenen, Abra, brokkelster, zeester

SW2-03: relatief klein monster, zand, enkele wormen 


\section{Bijlage 5 Geselecteerde locaties voor uitwerking in de huidige studie}

De twintig geselecteerde monsters (Ster) voor nadere uitwerking. Volle cirkels voor gerealiseerde monsters en lege cirkels voor mislukte (verplaatste) monsters.
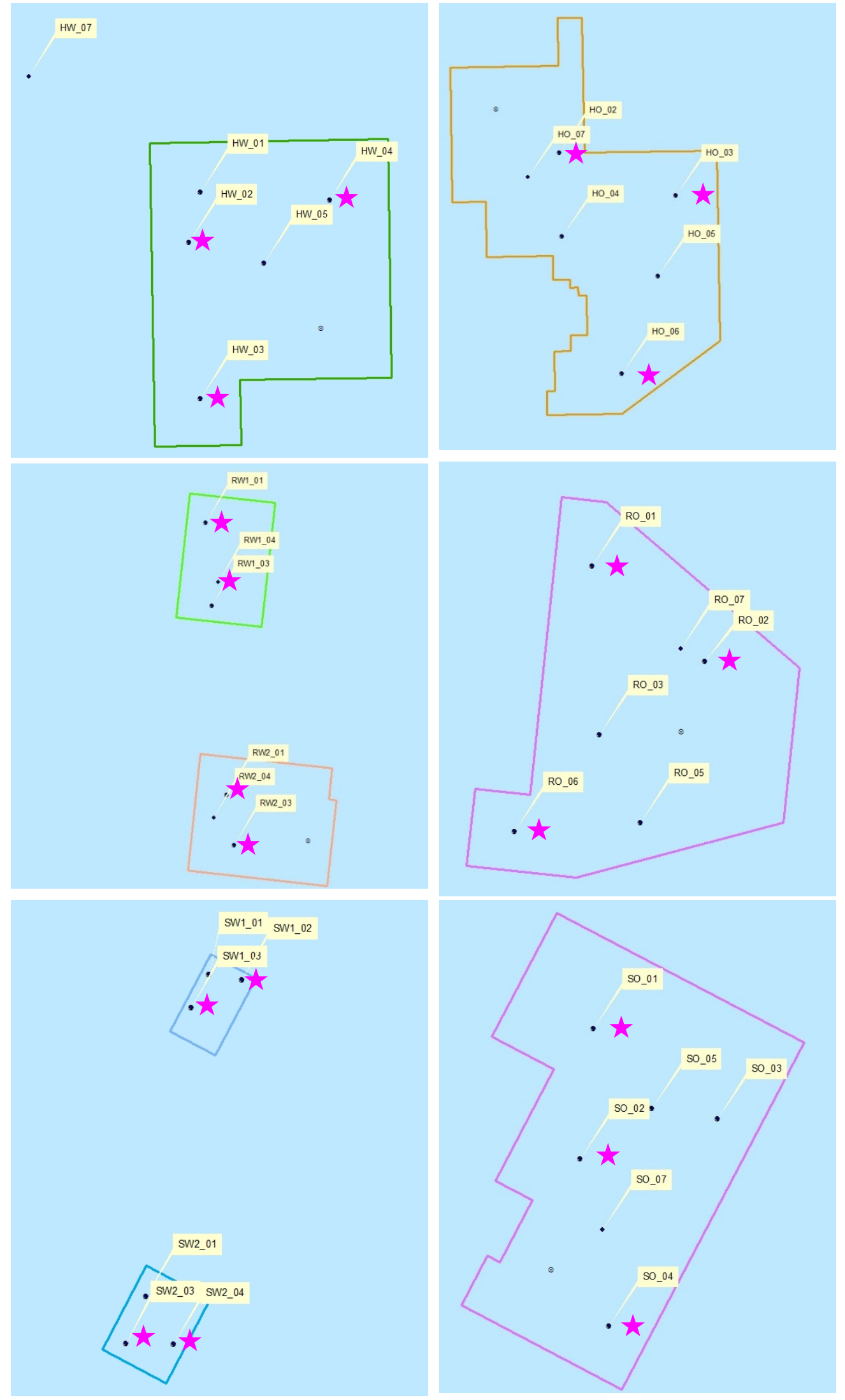


\section{Bijlage 6 Quickscan van de overige 16 monsters.}

\begin{tabular}{|c|c|c|c|c|c|c|c|c|c|c|c|c|c|c|c|c|c|c|}
\hline & locatienumme & ir HO_04 & HO_O5 & HO_O7 & RO_O3 & RO_05 & RO_07 & So_03 & So_05 & So__o & HW_01 & HW_05 & HW_07 & $\mathrm{RW}_{1} \_03$ & RW2__4 & Sw1_01 & SW2_-01 & $\begin{array}{l}\text { Percentage } \\
\text { voorkomen }\end{array}$ \\
\hline & Gebied & os & os & os & os & os & os & os & os & os & vo & vo & vo & vD & vo & vo & vo & \\
\hline & liter & 15 & 8 & 11 & 7.5 & 12.5 & 4.5 & 12.5 & 12.5 & 18.5 & 6.5 & 15 & 4 & 9.5 & 2.5 & 6.6 & 10 & \\
\hline & $\begin{array}{l}\text { Bodemleven / } \\
\text { Opmerking }\end{array}$ & $\begin{array}{l}\text { veel } \\
\text { mosselpeulen } \\
\text { /mosselen / } \\
\text { steen }\end{array}$ & $\begin{array}{l}\text { gruis/ } \\
\text { steen/ } \\
\text { zand / } \\
\text { fossiele } \\
\text { schelpen }\end{array}$ & $\begin{array}{l}\text { mosselen / } \\
\text { brokkelster }\end{array}$ & $\begin{array}{l}\text { veel gruis } \\
\text { / oude } \\
\text { schelpen }\end{array}$ & $\begin{array}{l}\text { steen / } \\
\text { brokkelster } \\
\text { /zandig/ } \\
\text { kleidelelen / } \\
\text { Sabella } /\end{array}$ & $\begin{array}{l}\text { veel gruis } \\
\text { / enkele } \\
\text { anemonen } \\
\text { /zeester/ } \\
\text { Sabella/ }\end{array}$ & $\begin{array}{l}\text { vnl. gruis / } \\
\text { mosselpe } \\
\text { ulen }\end{array}$ & kleiig/ & $\begin{array}{l}\text { veel } \\
\text { mossel- } \\
\text { peulen/ } \\
\text { weinig } \\
\text { leven / } \\
\text { gruis }\end{array}$ & $\begin{array}{l}\text { gruis/ } \\
\text { steen / } \\
\text { brokkelsters }\end{array}$ & $\begin{array}{l}\text { zand/ } \\
\text { gruis / } \\
\text { mossel-1 } \\
\text { peulen/ } \\
\text { steen }\end{array}$ & $\begin{array}{l}\text { brokkelster } \\
\text { /fijn zand I } \\
\text { veel Lanice } \\
\text { / Abra / } \\
\text { tapitschel } \\
\text { p/mossel- } \\
\text { peulen }\end{array}$ & $\begin{array}{l}\text { Sabella/ } \\
\text { mosselpe } \\
\text { ulen / } \\
\text { steen / } \\
\text { bagger }\end{array}$ & $\begin{array}{l}\text { gruis / } \\
\text { anemoon } \\
\text { /Arba I } \\
\text { brokkel Iste } \\
\text { r/steen }\end{array}$ & $\begin{array}{l}\text { gruis / } \\
\text { zeester/ } \\
\text { brokkelster } \\
\text { / Sabellla / } \\
\text { steen }\end{array}$ & $\begin{array}{l}\text { mossel- } \\
\text { peulen-n } \\
\text { beetie } \\
\text { stank }\end{array}$ & \\
\hline & Datum & 27/Aug & 27/Aug & 28/Aug & 26/Aug & 26/Aug & 28/Aug & ; 28/Aug & 28/Aug & 28/Aug & 27/Aug & 27/Aug & 27/Aug & 26/Aug & 27/Aug & $27 /$ Aug & 27/Aug & \\
\hline Abludomelita obtusata & ABLUOBTU & $20-50$ & $20-50$ & $20-50$ & $20-50$ & $10-20$ & 20-50 & $20-50$ & $10-20$ & $20-50$ & $20-50$ & 50-100 & $20-50$ & $10-20$ & $10-20$ & $10-20$ & $20-50$ & 100 \\
\hline Ophiura sp. & OPHISPEC & & 1-10 & 1-10 & $20-50$ & $20-50$ & $10-20$ & $20-50$ & & 1-10 & $1-10$ & 1-10 & $1-10$ & $10-20$ & $10-20$ & 1-10 & $1-10$ & 88 \\
\hline Actiniaria & ACTINASP & & & $1-10$ & $10-20$ & $20-50$ & $10-20$ & $10-20$ & $20-50$ & 1-10 & $20-50$ & $10-20$ & $50-100$ & & $50-100$ & $20-50$ & $10-20$ & 81 \\
\hline Glycera sp. & GLYCSPEC & & 1-10 & 1-10 & 1-10 & $1-10$ & 1-10 & $1-10$ & & 1-10 & $1-10$ & 1-10 & & $1-10$ & $10-20$ & 1-10 & 1-10 & 81 \\
\hline Nemertea & NEMERTSP & $1-10$ & & 1-10 & $10-20$ & $1-10$ & $10-20$ & $1-10$ & $20-50$ & $10-20$ & $1-10$ & $10-20$ & $1-10$ & $10-20$ & & & $1-10$ & 81 \\
\hline Oligochaeta & OLGOCSP & $1-10$ & $10-20$ & $10-20$ & & $20-50$ & & 5 & $20-50$ & & 5 & 1-10 & $20-50$ & $>500$ & $>500$ & 5 & $20-50$ & 81 \\
\hline Lanice conchilega & LANICONC & & & & $1-10$ & $20-50$ & 1-10 & $20-50$ & $10-20$ & & $1-10$ & 1-10 & $50-100$ & $1-10$ & $1-10$ & $1-10$ & $1-10$ & 75 \\
\hline Asterias rubens & ASTERUBE & $1-10$ & & 1-10 & 1-10 & & $1-10$ & $10-20$ & $1-10$ & 1-10 & & 1-10 & $1-10$ & & & $1-10$ & $1-10$ & 69 \\
\hline Ophiothrix fragilis & OPHXFRAG & $20-50$ & 1-10 & $20-50$ & $1-10$ & $10-20$ & & & & & $10-20$ & & $20-50$ & $1-10$ & $10-20$ & 1-10 & $1-10$ & 69 \\
\hline Mediomastus sp. & MEDISPEC & & & 1-10 & & $1-10$ & & & $20-50$ & 1-10 & $10-20$ & & $10-20$ & 1-10 & $20-50$ & $10-20$ & 1-10 & 63 \\
\hline Phyllodoce mucosa & PHYLMUCO & $1-10$ & 1-10 & $1-10$ & & $1-10$ & & $1-10$ & & 1-10 & $1-10$ & & $1-10$ & 1-10 & & & $1-10$ & 63 \\
\hline Abra alba & ABRAALBA & & & & & $10-20$ & & $1-10$ & & $1-10$ & & & $1-10$ & $20-50$ & $50-100$ & $1-10$ & $1-10$ & 50 \\
\hline Caprellidae & CAPRELSP & & & & 1-10 & & 1-10 & $1-10$ & $1-10$ & & & 1-10 & & $1-10$ & $1-10$ & $1-10$ & & 50 \\
\hline Lysianassidae & LYSIANSP & $1-10$ & & 1-10 & $10-20$ & $1-10$ & & & & 1-10 & & 1-10 & & $1-10$ & $1-10$ & & & 50 \\
\hline Pisidia longicornis & PISDLONG & $1-10$ & 1-10 & 1-10 & & $1-10$ & & $1-10$ & & & $1-10$ & 1-10 & & $1-10$ & & & & 50 \\
\hline Sabella pavonina & SABLPAVO & & & & 1-10 & $20-50$ & $10-20$ & $1-10$ & $1-10$ & 1-10 & & & & $20-50$ & & & $1-10$ & 50 \\
\hline Sthenelais boa & STHEBOA & & & & & $1-10$ & & $1-10$ & $1-10$ & 1-10 & & & $1-10$ & & $10-20$ & $1-10$ & $1-10$ & 50 \\
\hline Eumida sp. & EUMISPEC & $1-10$ & & 1-10 & & $10-20$ & & $10-20$ & $10-20$ & & & & $20-50$ & $1-10$ & & & & 44 \\
\hline Hesionidae sp. & HESIONSP & $1-10$ & & & & & 1-10 & & $1-10$ & 1-10 & & $1-10$ & $1-10$ & & & & $1-10$ & 44 \\
\hline Aora typica & AORATYPI & & $10-20$ & & 1-10 & & & $1-10$ & $1-10$ & 1-10 & & & & & & & $1-10$ & 38 \\
\hline Nereidae & NERESPEC & & & & & $1-10$ & & & $10-20$ & & & & $10-20$ & $10-20$ & & 1-10 & $1-10$ & 38 \\
\hline Polynoidae & POLNSPEC & & & & & $1-10$ & & $1-10$ & $10-20$ & & & & $1-10$ & $1-10$ & 1-10 & & & 38 \\
\hline Syllidia armata & SYDIARMA & & 1-10 & 1-10 & & & & & $1-10$ & 1-10 & & & & $1-10$ & $1-10$ & & & 38 \\
\hline Pholoe sp. & PHOLSPEC & & & & & $1-10$ & & $1-10$ & $1-10$ & & & & & & $1-10$ & $1-10$ & & 31 \\
\hline Cirriformia tentaculata & CIRFTENT & & & & 1-10 & & 1-10 & & 1-10 & & $1-10$ & & & & & 1-10 & & 31 \\
\hline Bodotria sp. & BODOSPEC & & & & 1-10 & & & $1-10$ & & & & & & & 1-10 & & 1-10 & 25 \\
\hline Notomastus latericeus & NOTOLATE & & & & & $1-10$ & & $1-10$ & $1-10$ & & & & & & $10-20$ & & & 25 \\
\hline Pycnogonidae & PYCNINDE & & & & $1-10$ & & $1-10$ & & & 1-10 & & & & $10-20$ & & & & 25 \\
\hline Aonides oxycephala & AONIOXYC & & & & & & & & $1-10$ & & $1-10$ & & & & $1-10$ & & & 19 \\
\hline Capitella sp. & CAPISPEC & & $1-10$ & 1-10 & & & & & & & & & & & & $1-10$ & & 19 \\
\hline Carcinus maenas & CARCMAEN & & 1-10 & & & & & $1-10$ & & & & & $1-10$ & & & & & 19 \\
\hline Liocarcinus sp. & LOCSPEC & & & & & & & & & & & & & & $1-10$ & 1-10 & $1-10$ & 19 \\
\hline Mytilus edulis & MYTIEDUL & $10-20$ & 1-10 & & $1-10$ & & & & & & & & & & & & & 19 \\
\hline Polydora sp. & POLDSPEC & $1-10$ & $1-10$ & 1-10 & & & & & & & & & & & & & & 19 \\
\hline Callianassa sp. & CALLSPEC & & & & & & & & $1-10$ & & & & & & & 1-10 & & 13 \\
\hline Ensis sp. & ENSISPEC & & & & & & & & & & & 1-10 & $1-10$ & & & & & 13 \\
\hline Nephtys sp. & NEPHSPEC & & & & & $1-10$ & & & & & & & & & 1-10 & & & 13 \\
\hline Pectinaria & PECTINSP & & & & & $1-10$ & & & & & & & & & & $1-10$ & & 13 \\
\hline Venerupis corrugata & VENECORR & & & & & & & & & 1-10 & & & & & & & 1-10 & 13 \\
\hline Barnea candida & BARNCAND & & & & & & & & & 1-10 & & & & & & & & 6 \\
\hline Corophiidae & COROSPEC & & & & & & & & & & $1-10$ & & & & & & & 6 \\
\hline Eteone sp. & ETEOSPEC & & & & & & & & & & $1-10$ & & & & & & & 6 \\
\hline Fabulina fabula & FABUFABU & & & & & & & & & & & & & & 1-10 & & & 6 \\
\hline Flabelligera affinis & FLABAFFI & & & & & $1-10$ & & & & & & & & & & & & 6 \\
\hline Glycera tridactyla & GLYCTRID & & & & & & & & $1-10$ & & & & & & & & & 6 \\
\hline Ischyroceridae & ISCHYDSP & & & & & & & & & & & & & & 1-10 & & & 6 \\
\hline Jaera sp. & JAERSPEC & & & & & & & & & & & & & & & 1-10 & & 6 \\
\hline Necora puber & NECOPUBE & & & & & & & & & & & 1-10 & & & & & & 6 \\
\hline Nudibranchia & NUDBRSP & & & & & & & & $1-10$ & & & & & & & & & 6 \\
\hline Petricolaria pholadiformis & PETRPHOL & & & & & & & $1-10$ & & & & & & & & & & 6 \\
\hline Phoronida & PHORONID & & & & & & & & $1-10$ & & & & & & & & & 6 \\
\hline Platyhelminthes & PLATYHSP & $1-10$ & & & & & & & & & & & & & & & & 6 \\
\hline
\end{tabular}




\section{Bijlage 7 Typische soorten habitattype H1160 'Grote baaien' (H1160 versie 18 dec 2008)}

\section{Typische soorten}

Conform de Habitatrichtlijn worden voor alle habitattypen zogenaamde 'typische soorten' geselecteerd, die gezamenlijk een goede kwaliteitsindicator vormen voor de (compleetheid van de) levensgemeenschap van het habitattype. De set van typische soorten is een indicator voor de kwaliteit (en daarmee de staat van instandhouding) van het habitattype op landelijk niveau.

Als typische soort voor $\mathrm{H} 1160$ worden soorten geselecteerd op basis van de volgende criteria:

- de soorten zijn meetbaar en opgenomen in de bestaande monitoringprogramma's;

- de soorten worden dusdanig regelmatig aangetroffen, dat trends en/of verspreiding kunnen worden vastgesteld (en dus niet regionaal (zeer) zeldzaam zijn);

- de soorten zijn geen exoot (een exoot is door toedoen van de mens sinds 1900 geïntroduceerd);

- de soorten zijn bruikbaar als indicator van een goede abiotische toestand of goede biotische structuur.

$\mathrm{H} 1160$ is intern gestructureerd uit meerdere ecotopen en de daarmee geassocieerde soorten. De onderstaande lijst van typische soorten bevat dus soorten typisch voor zowel de droogvallende delen als de dynamischer geulen en zandbanken van de waterkolom daarboven en soorten die typisch zijn voor harde substraten zoals de mosselbanken.

Het is geenszins de bedoeling een lijst op te nemen van álle typische soorten die in de levensgemeenschap van het habitattype voorkomen. Niet alle trofische niveaus (primaire producenten, zooplankton, grote predatoren) en soortgroepen (bijvoorbeeld naaktslakken, wieren) zijn dan ook vertegenwoordigd. Het geheel van thans geselecteerde soorten is zodanig dat daarmee de kwaliteit van de habitat genoegzaam kan worden beoordeeld.

De onderstaande lijst van typische soorten is op basis van bovenstaande criteria samen gesteld; de lijst wijkt daarmee af van de rapportage van 2007 aan de Europese Commissie.

\begin{tabular}{|l|l|l|l|}
\hline Nederlandse naam & Wetenschappelijke naam & Soortgroep & Categorie $^{2}$ \\
\hline Zeeanjelier & Metridium senile & Bloemdieren & Cab \\
\hline Wadpier & Arenicola marina & Borstelwormen & \\
\hline Schelpkokerworm & Lanice conchilega & Borstelwormen & $\mathrm{Ca}$ \\
\hline Zandzager & Nephtys hombergii & Borstelwormen & $\mathrm{Ca}$ \\
\hline Zeeduizendpoot & Nereis diversicolor & Borstelwormen & $\mathrm{Ca}$ \\
\hline Gewone strandkrab & Carcinus maenas & Kreeftachtigen & $\mathrm{Cab}$ \\
\hline Buldozerkreeftje & Urothoe poseidonis & Kreeftachtigen & $\mathrm{Ca}$ \\
\hline Groot zeegras & Zostera marina & Vaatplanten & $\mathrm{Ca}$ \\
\hline Klein zeegras & Zostera noltii & Vaatplanten & $\mathrm{K}+\mathrm{Ca}$ \\
\hline Bot & Platichthys flesus & Vissen & $\mathrm{Cab}$ \\
\hline Haring & Clupea harengus & Vissen & $\mathrm{Cab}[\mathrm{h} . \mathrm{j} .1]$ \\
\hline Puitaal & Zoarces viviparus & Vissen & $\mathrm{Ca}$ \\
\hline Schar & Limanda limanda & Vissen & $\mathrm{Ca}$ \\
\hline Schol & Pleuronectes platessa & Vissen & $\mathrm{Ca}$ \\
\hline Steenbolk & Trisopterus luscus & Vissen & $\mathrm{Ca}$ \\
\hline Wijting & Merlangius merlangius & Vissen & $\mathrm{Cab}$ \\
\hline Zeedonderpad & Myoxocephalus scorpius & Vissen & $\mathrm{Ca}$ \\
\hline Hartegel & Echinocardium cordatum & Stekelhuidigen & $\mathrm{Ca}$ \\
\hline Kokkel & Cerastoderma edule & Weekdieren & $\mathrm{Ca}$ \\
\hline Mossel & Mytilus edulis & Weekdieren & $\mathrm{Ca}$ \\
\hline
\end{tabular}

${ }^{2}$ Tot de typische soorten worden gerekend: $\mathrm{Ca}=$ constante soort met indicatie voor goede abiotische toestand; $\mathrm{Cb}=$ constante soort met indicatie voor goede biotische structuur; $\mathrm{Cab}=$ constante soort met indicatie voor goede abiotische toestand en goede biotische structuur; $\mathrm{K}=$ karakteristieke soort; $\mathrm{E}=$ exclusieve soort 


\section{Bijlage 8 Typische soorten habitattype H1110 permanent overstroomde zandbanken (Noordzee-kustzone) (2014)}

De lijst van typische soorten van subtype $\mathrm{H} 1110 \mathrm{~B}$ bevat soorten die kenmerkend zijn voor de dynamische zandbanken en geulen in de kustzone tot 20 meter diepte.

\begin{tabular}{|l|l|l|l|}
\hline Nederlandse naam & Wetenschappelijke naam & Soortgroep & Categorie $^{\mathbf{8}}$ \\
\hline Schelpkokerworm & Lanice conchilega & Borstelwormen & Cab \\
\hline Zandkokerworm & Spiophanes bombyx & Borstelwormen & Cab \\
\hline & Nephtys cirrosa & Borstelwormen & Ca \\
\hline & Nephtys hombergii & Borstelwormen & Ca \\
\hline Kniksprietkreeftje & Magelona papillicornis & Borstelwormen & Ca \\
\hline Gewone zwemkrab & Bathyporeia elegans & Kreeftachtigen & Ca \\
\hline Bulldozerkreeftje & Liocarcinus holsatus & Kreeftachtigen & Ca \\
\hline Gewone heremietkreeft & Urothoe poseidonis & Kreeftachtigen & Ca \\
\hline & Pagurus bernhardus & Kreeftachtigen & Ca \\
\hline Hartegel & Pontocrates altamarinus & Kreeftachtigen & Ca \\
\hline Gewone slangster & Echinocardium cordatum & Stekelhuidigen & Ca \\
\hline Dwergtong & Ophiura ophiura & Stekelhuidigen & Ca \\
\hline
\end{tabular}

\footnotetext{
${ }^{7}$ De onderstaand opgenomen lijsten van typische soorten van $\mathrm{H} 1110 \mathrm{~A}$ en H1110B zijn geactualiseerd en wijken daarom af van de met de artikel 17 rapportage van 2007 aan de Europese Commissie gezonden lijsten.

${ }^{8}$ Tot de typische soorten worden gerekend: $\mathrm{Ca}=$ constante soort met indicatie voor goede abiotische toestand; $\mathrm{Cb}=$ constante soort met indicatie voor goede biotische structuur; $\mathrm{Cab}=$ constante soort met indicatie voor goede abiotische toestand en goede biotische structuur; $\mathrm{K}=$ karakteristieke soort; $\mathrm{E}=$ exclusieve soort.
} 


\section{Bijlage 9 Frequentie van voorkomen MWTL OS monitoringsprogramma en deze studie (OS monsters)}

\begin{tabular}{|c|c|c|c|c|}
\hline Oosterschelde & Frequentie MWTL & Soortcode & Frequentie deze studii & ii Opmerkingen \\
\hline Scoloplos armiger & $96 \%$ & SCOPARMX & 22 & \\
\hline Spiophanes bombyx & $83 \%$ & SPIPBOMB & 01 & Niet waargenomen OS zijde, wel VD \\
\hline Nephtys & $67 \%$ & NEPHSPEC & 11 & \\
\hline Nephtys cirrosa & $66 \%$ & NEPHCIRR & 01 & Niet waargenomen OS zijde, wel VD \\
\hline Abra alba & $44 \%$ & ABRAALBA & 56 & \\
\hline Lanice conchilega & $42 \%$ & LANICONC & 78 & \\
\hline Magelona johnstoni & $41 \%$ & MAGEJOHN & 01 & Niet waargenomen OS zijde, wel VD \\
\hline Oligochaeta & $40 \%$ & OLIGOCSP & 89 & \\
\hline Nephtys hombergii & $37 \%$ & NEPHHOMB & 0 & Niet waargenomen OS zijde, wel VD \\
\hline Urothoe poseidonis & $35 \%$ & UROTPOSE & 01 & Niet waargenomen OS zijde, wel VD \\
\hline Cirratulidae & $35 \%$ & CIRRATSP & 56 & \\
\hline Nemertea & $35 \%$ & NEMERTSP & 100 & \\
\hline Notomastus latericeus & $32 \%$ & NOTOLATE & 56 & \\
\hline Capitella & $30 \%$ & CAPISPEC & 89 & \\
\hline Poecilochaetus serpens & $30 \%$ & POECSERP & 01 & Niet waargenomen OS zijde, wel VD \\
\hline Actiniaria & $30 \%$ & ACTINASP & 100 & \\
\hline Aricidea (Aricidea) minuta & $29 \%$ & & & Niet waargenomen in deze studie \\
\hline Kurtiella bidentata & $28 \%$ & KURTBIDE & 44 & \\
\hline Urothoe brevicornis & $28 \%$ & UROTPOSE & 02 & Zelfde genus, andere soort, Niet waargenomen OS zijde, wel VD \\
\hline Mytilidae & $26 \%$ & MYTIEDUL & 781 & In deze studie tot op soort gebracht \\
\hline Glycera tridactyla & $26 \%$ & GLYCSPEC & 33 & \\
\hline Pseudopolydora pulchra & $26 \%$ & PSPDPULC & 11 & \\
\hline Fabulina fabula & $24 \%$ & FABUFABU & 01 & Niet waargenomen OS zijde, wel VD \\
\hline Abludomelita obtusata & $24 \%$ & ABLUOBTU & 100 & \\
\hline Pholoe inornata & $24 \%$ & PHOLINOR & 44 & \\
\hline Eunereis longissima & $23 \%$ & EUNELONG & 78 & \\
\hline Echinocardium cordatum & $22 \%$ & & & Niet waargenomen in deze studie \\
\hline Glycera & $22 \%$ & GLYCTRID & 1001 & In deze studie tot op soort gebracht \\
\hline Spio martinensis & $20 \%$ & SPIOMART & 01 & Niet waargenomen OS zijde, wel VD \\
\hline Aoridae & $20 \%$ & AORATYPI & 1001 & In deze studie tot op soort gebracht \\
\hline Tellimya ferruginosa & $20 \%$ & & & Niet waargenomen in deze studie \\
\hline Polynoidae & $20 \%$ & & & Verschillende soorten uit deze familie aangetroffen \\
\hline Tellinoidea & $19 \%$ & & & Verschillende soorten uit deze superfamilie aangetroffen \\
\hline Phyllodoce mucosa & $19 \%$ & PHYLMUCO & 100 & \\
\hline Ensis & $18 \%$ & ENSISPEC & 01 & Niet waargenomen OS zijde, wel VD \\
\hline Ampelisca brevicornis & $17 \%$ & & & Niet waargenomen in deze studie \\
\hline Anoplodactylus petiolatus & $17 \%$ & ANOPPETI & 33 & \\
\hline Pariambus typicus & $17 \%$ & & & Niet waargenomen in deze studie \\
\hline Ophiuroidea & $16 \%$ & OPHISPEC & 1001 & In alle monsters Ophiura spp. \\
\hline Bathyporeia elegans & $16 \%$ & & & Niet waargenomen in deze studie \\
\hline Phyllodoce & $16 \%$ & PHYLMUCO & 1001 & In deze studie tot op soort gebracht \\
\hline Sthenelais boa & $15 \%$ & STHEBOA & 67 & \\
\hline Ophiura ophiura & $15 \%$ & OPHIOPHI & 01 & In alle monsters Ophiura spp. \\
\hline Crangon crangon & $15 \%$ & & & Niet waargenomen in deze studie \\
\hline Mediomastus fragilis & $15 \%$ & MEDISPEC & 100 & \\
\hline Eumida & $15 \%$ & EUMISPEC & 22 & \\
\hline Crepidula fornicata & $15 \%$ & CREPFORN & 0 & Niet waargenomen OS zijde, wel VD \\
\hline Phtisica marina & $15 \%$ & PHTIMARI & 56 & \\
\hline Phyllodocidae & $14 \%$ & PHYLMUCO & 100 & Verschillende soorten uit deze familie waargenomen \\
\hline Abra & $14 \%$ & ABRASPEC & 0 & \\
\hline Malmgrenia darbouxi & $14 \%$ & MALGDARB & 11 & \\
\hline Veneridae & $14 \%$ & & & Verschillende soorten uit deze familie waargenomen \\
\hline Mytilus edulis & $13 \%$ & MYTIEDUL & 78 & \\
\hline Gastrosaccus spinifer & $13 \%$ & & & Niet waargenomen in deze studie \\
\hline Achelia echinata & $13 \%$ & ACHEECHI & 78 & \\
\hline Ensis leei & $13 \%$ & ENSILEEI & 0 & Niet waargenomen OS zijde, wel VD \\
\hline Asterias rubens & $13 \%$ & ASTERUBE & 89 & \\
\hline Magelona & $13 \%$ & & & Magelona johnstoni waargenomen in deze studie \\
\hline Eteone & $12 \%$ & ETEOSPEC & 11 & \\
\hline Venerupis corrugata & $12 \%$ & VENECORR & 22 & \\
\hline Microphthalmus & $12 \%$ & MICRSPEC & 44 & \\
\hline Heteromastus filiformis & $11 \%$ & & & Niet waargenomen in deze studie \\
\hline Nereididae & $11 \%$ & NERESPEC & 11 & \\
\hline Myrianida & $11 \%$ & MYRNSPEC & 78 & \\
\hline Spio & $11 \%$ & SPIONISP & 0 & Twee soorten van dit genus aangetroffen \\
\hline Corophiidae & $11 \%$ & & & Wel soort uit deze familie waargenomen \\
\hline Terebellidae & $11 \%$ & & & Wel soorten uit deze familie waargenomen \\
\hline Autolytinae & $11 \%$ & & & Niet waargenomen in deze studie \\
\hline Magelona mirabilis & $11 \%$ & & & Wel Magelona johnstoni waargenomen in deze studie \\
\hline Ophiura albida & $10 \%$ & & & In alle monsters komt Ophiura sp. Voor \\
\hline Owenia fusiformis & $10 \%$ & OWENFUSI & 11 & \\
\hline Pontocrates altamarinus & $10 \%$ & PONTALTA & 0 & Niet waargenomen OS zijde, wel VD \\
\hline Monocorophium acherusicum & $10 \%$ & MONCACHE & 33 & \\
\hline
\end{tabular}




\section{Bijlage 10 Frequentie van voorkomen PMR Voordelta monitoringsprogramma en deze studie (VD monsters)}

\begin{tabular}{|c|c|c|c|c|}
\hline Voordelta & Frequentie PMR & Soortcode & Frequentie deze studiı & Opmerkingen \\
\hline Spiophanes bombyx & $71 \%$ & SPIPBOMB & 36 & \\
\hline Nephtys cirrosa & $60 \%$ & NEPHCIRR & 27 & \\
\hline Nemertea & $59 \%$ & NEMERTSP & 45 & \\
\hline Urothoe poseidonis & $56 \%$ & UROTPOSE & 9 & \\
\hline Echinocardium cordatum & $55 \%$ & & & Niet waargenomen in deze studie \\
\hline Eteone & $48 \%$ & ETEOSPEC & 18 & \\
\hline Tellimya ferruginosa & $45 \%$ & & & Niet waargenomen in deze studie \\
\hline Lanice conchilega & $42 \%$ & LANICONC & 55 & \\
\hline Scoloplos & $40 \%$ & SCOPARMX & 45 & In deze studie tot op soort gebracht (Scoloplos armiger) \\
\hline Nephtys & $40 \%$ & NEPHSPEC & 9 & \\
\hline Abra alba & $38 \%$ & ABRAALBA & 73 & \\
\hline Ensis directus & $38 \%$ & ENSILEEI & 9 & \\
\hline Kurtiella bidentata & $37 \%$ & KURTBIDE & 55 & \\
\hline Fabulina fabula & $36 \%$ & FABUFABU & 18 & \\
\hline Oligochaeta & $36 \%$ & OLIGOCSP & 55 & \\
\hline Heteromastus filiformis & $35 \%$ & & & Niet waargenomen in deze studie \\
\hline Poecilochaetus serpens & $34 \%$ & POECSERP & 18 & \\
\hline Eunereis longissima & $34 \%$ & EUNELONG & 45 & \\
\hline Notomastus latericeus & $34 \%$ & NOTOLATE & 55 & \\
\hline Nephtys hombergii & $32 \%$ & NEPHHOMB & 27 & \\
\hline Leucothoe incisa & $32 \%$ & & & Niet waargenomen in deze studie \\
\hline Actiniaria & $30 \%$ & ACTINASP & 73 & \\
\hline Eumida & $27 \%$ & EUMISANG & 36 & In deze studie tot op soort gebracht (Eumida sanguinea) \\
\hline Phoronidae & $25 \%$ & PHORONID & 9 & \\
\hline Owenia fusiformis & $24 \%$ & OWENFUSI & 27 & \\
\hline Ensis & $23 \%$ & ENSISPEC & 9 & \\
\hline Scoloplos armiger & $23 \%$ & SCOPARMX & 45 & \\
\hline Phyllodoce mucosa & $20 \%$ & PHYLMUCO & 55 & \\
\hline Magelona johnstoni & $19 \%$ & MAGEJOHN & 18 & \\
\hline Abludomelita obtusata & $19 \%$ & ABLUOBTU & 55 & \\
\hline Ophiura albida & $18 \%$ & OPHISPEC & 82 & In alle monsters Ophiura sp. \\
\hline Ophiura ophiura & $18 \%$ & OPHIOPHI & 9 & \\
\hline Phoronida & $18 \%$ & PHORONID & 9 & \\
\hline Lagis koreni & $18 \%$ & LAGIKORE & 45 & \\
\hline Pestarella tyrrhena & $17 \%$ & & & Niet waargenomen in deze studie \\
\hline Malmgrenia lunulata & $16 \%$ & MALMSPEC & 45 & \\
\hline Magelona papillicornis & $15 \%$ & & & Wel Magelona johnstoni waargenomen \\
\hline Processa parva & $15 \%$ & & & Niet waargenomen in deze studie \\
\hline Mediomastus fragilis & $14 \%$ & MEDISPEC & 55 & In deze studie niet tot op soort gebracht \\
\hline Capitella capitata & $14 \%$ & CAPISPEC & 27 & In deze studie niet tot op soort gebracht \\
\hline Spio martinensis & $13 \%$ & SPIOMART & 9 & \\
\hline Spio & $13 \%$ & & & In deze studie tot op soort gebracht (Spio martinensis, Spio filicornis) \\
\hline Euspira nitida & $13 \%$ & & & Niet waargenomen in deze studie \\
\hline Tellinoidea & $12 \%$ & & & Wel soorten uit deze familie waargenomen \\
\hline Caprellidae & $12 \%$ & CAPRELSP & 27 & \\
\hline Magelona mirabilis & $11 \%$ & & & Wel Magelona johnstoni waargenomen in deze studie \\
\hline Gastrosaccus spinifer & $11 \%$ & & & Niet waargenomen in deze studie \\
\hline Phyllodoce & $10 \%$ & PHYLMUCO & 55 & In deze studie tot op soort gebracht \\
\hline Nereis & $10 \%$ & NERESPEC & 0 & \\
\hline Bathyporeia guilliamsoniana & $10 \%$ & & & Niet waargenomen VD zijde, wel OS \\
\hline Urothoe brevicornis & $10 \%$ & & & Wel Urothoe poseidonis waargenomen \\
\hline
\end{tabular}




\section{Bijlage 11 Mediane korrelgrootte $(\mu \mathrm{m})+$ sediment omschrijving van de 36 monsters.}

\begin{tabular}{|l|l|l|}
\hline Locatie & Mediane korrelgrootte & Omschrijving \\
\hline Oosterschelde & & \\
\hline HO_02 & 371 & zeer grof zand \\
\hline HO_03 & 255 & matig grof zand \\
\hline HO_04 & 199 & matig fijn zand \\
\hline HO_05 & 305 & zeer grof zand \\
\hline HO_06 & 268 & matig grof zand \\
\hline HO_07 & 397 & zeer grof zand \\
\hline RO_01 & 440 & uiterst grof zand \\
\hline RO_02 & 431 & uiterst grof zand \\
\hline RO_03 & 534 & uiterst grof zand \\
\hline RO_05 & 244 & matig grof zand \\
\hline RO_06 & 209 & matig fijn zand \\
\hline RO_07 & 411 & zeer grof zand \\
\hline SO_01 & 311 & zeer grof zand \\
\hline SO_02 & 150 & matig fijn zand \\
\hline SO_03 & 173 & matig fijn zand \\
\hline SO_04 & 135 & zeer fijn zand \\
\hline SO_05 & 220 & matig grof zand \\
\hline SO_07 & 130 & zeer fijn zand \\
\hline Voordelta & & \\
\hline HW_01 & 417 & zeer grof zand \\
\hline HW_02 & 273 & matig grof zand \\
\hline HW_03 & 241 & matig grof zand \\
\hline HW_04 & 395 & zeer grof zand \\
\hline HW_05 & 222 & matig grof zand \\
\hline HW_07 & 164 & matig fijn zand \\
\hline RW1_01 & 371 & zeer grof zand \\
\hline RW1_03 & 291 & matig grof zand \\
\hline RW1_04 & 221 & matig grof zand \\
\hline RW2_01 & 250 & matig grof zand \\
\hline RW2_03 & 209 & matig fijn zand \\
\hline RW2_04 & 223 & matig grof zand \\
\hline SW1_01 & 248 & matig grof zand \\
\hline SW1_02 & 188 & zeer grof zand \\
\hline SW1_03 & 245 & matig fijn zand \\
\hline SW2_01 & matig grof zand \\
\hline SW2_03 & matig grof zand \\
\hline SW2_04 & & matig grof zand \\
\hline & & \\
\hline
\end{tabular}


Wageningen Marine Research

$\mathrm{T}:+31(0) 317480900$

E: marine-research@wur.nl

www.wur.nl/marine-research

Bezoekers adres:

- Ankerpark 27, 1781 AG Den Helder

- Korringaweg 7, 4401 NT Yerseke

- Haringkade 1, 1976 CP IJmuiden
Wageningen Marine Research levert met kennis, onafhankelijk

wetenschappelijk onderzoek en advies een wezenlijke bijdrage aan een duurzamer, zorgvuldiger beheer, gebruik en bescherming van de natuurlijke rijkdommen in zee-, kust- en zoetwatergebieden.

Wageningen Marine Research is onderdeel van Wageningen University \& Research. Wageningen University \& Research is het samenwerkingsverband tussen Wageningen University en Stichting Wageningen Research en heeft als missie: 'To explore the potential of nature to improve the quality of life' 